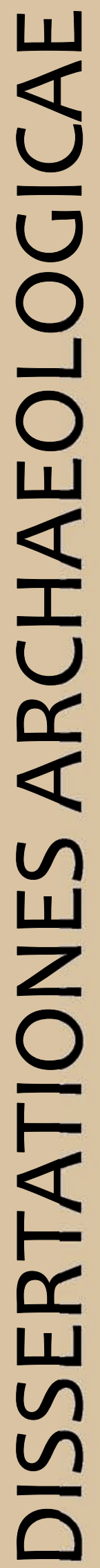

ex Instituto Archaeologico Universitatis de Rolando Eötvös nominatae

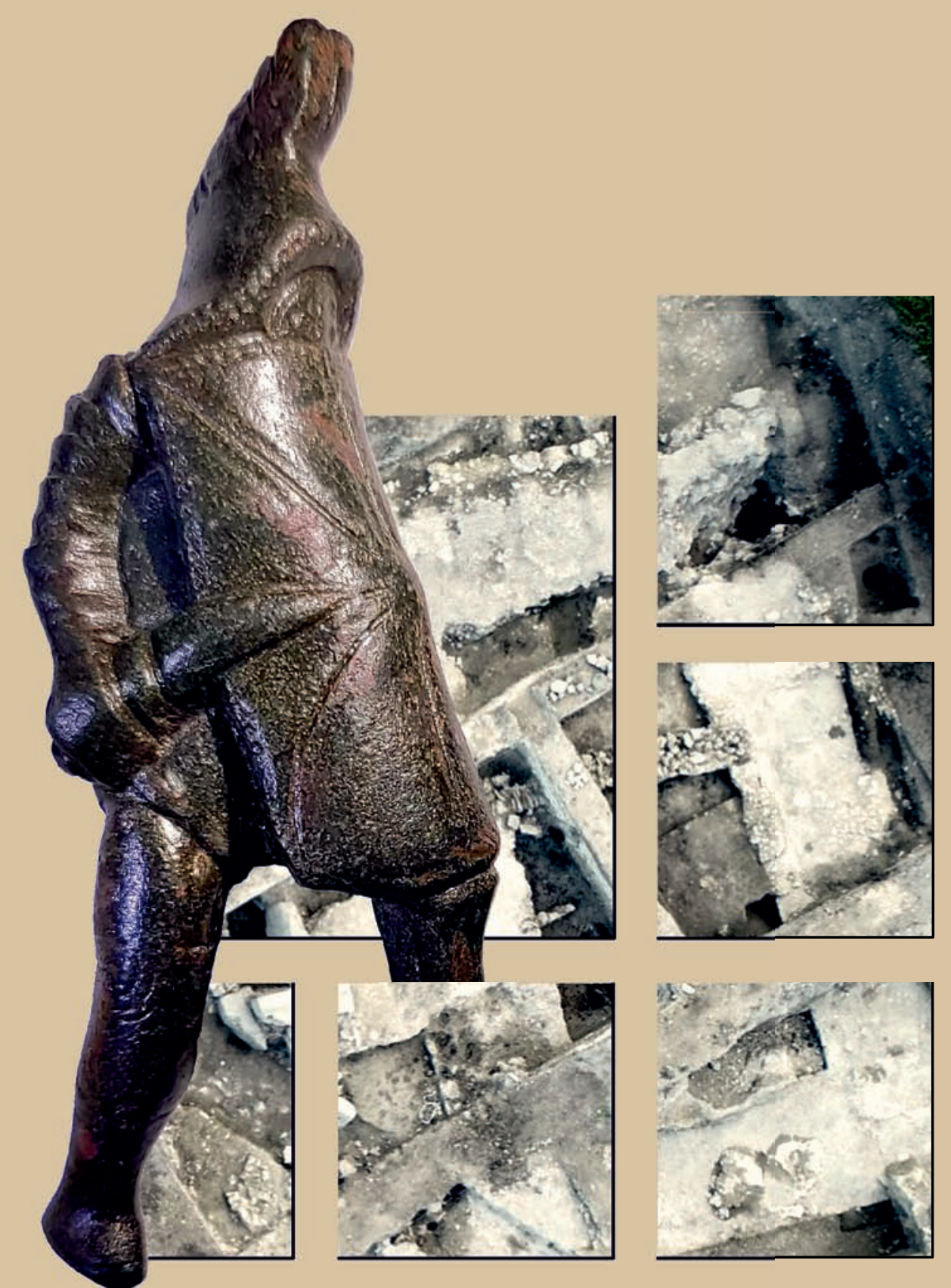

$$
\text { Ser. 3. No. 7. } 2019
$$




\section{Dissertationes Archaeologicae ex Instituto Archaeologico}

Universitatis de Rolando Eötvös nominatae Ser. 3. No. 7.

Budapest 2019 
Dissertationes Archaeologicae ex Instituto Archaeologico Universitatis de Rolando Eötvös nominatae

Ser. 3. No. 7.

Editor-in-chief:

DÁvid BARTUS

Editorial board:

LÁsZló BARTOSIEWICZ

LÁSZLÓ BORHY

ZOLTÁN CZAJLIK

IsTVÁN FELD

GÁBOR KALLA

PÁL RACZKY

MikLÓs SzABÓ

TivadAR VidA

Technical editor:

GÁBOR VÁCZI

Proofreading:

SZILVIA BARTUS-SZÖLLősI

ZsóFIA KondÉ

Aviable online at http://dissarch.elte.hu

Contact: dissarch@btk.elte.hu

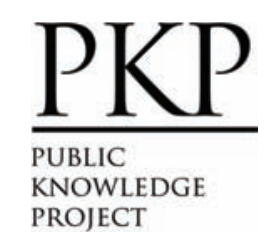

๑ ELTE Eötvös Loránd University, Institute of Archaeological Sciences

Layout and cover design: Gábor Váczi

Budapest 2019 


\section{CONTENTs}

\section{ARticles}

János Gábor TARBAY

The Casting Mould and the Wetland Find - New Data on the Late Bronze Age

Peschiera Daggers

Máté MeRvel

Late Bronze Age stamp-seals with negative impressions of seeds from Eastern Hungary

János Gábor TARBAY

Melted Swords and Broken Metal Vessels - A Late Bronze Age Assemblage

from Tatabánya-Bánhida and the Selection of Melted Bronzes

Ágnes ScHNEIDER

Multivariate Statistical Analysis of Archaeological Contexts: the case study

of the Early La Tène Cemetery of Szentlörinc, Hungary

Csilla SÁRÓ - Gábor LASSÁNYI

Bow-tie shaped fibulae from the cemetery of Budapest/Aquincum-Graphisoft Park

Dávid BARTus

Roman bronze gladiators - A new figurine of a murmillo from Brigetio

Kata DÉvAI

Re-Used Glass Fragments from Intercisa

Bence Simon

Rural Society, Agriculture and Settlement Territory in the Roman, Medieval and Modern Period Pilis Landscape

Rita RAKONCZAY

„Habaner“ Ofenkacheln auf der Burg Čabrad”

\section{FIELD REPORT}

Bence Simon - Anita Benes - Szilvia Joháczi - Ferenc BARnA

New excavation of the Roman Age settlement at Budapest dist. XVII, Péceli út (15127) site 


\section{Thesis Abstracts}

Kata SzILÁGYi

Die Silexproduktion im Kontext der Südosttransdanubischen Gruppe

der spätneolithischen Lengyel-Kultur

Norbert FARAGÓ

Complex, household-based analysis of the stone tools of Polgár-Csőszhalom

János Gábor TARBAY

Type Gyermely Hoards and Their Dating - A Supplemented Thesis Abstract

Zoltán Havas

The brick architecture of the governor's palace in Aquincum

Szabina Merva

'...circa Danubium...' from the Late Avar Age until the Early Árpádian Age-

$8^{\text {th }}-11^{\text {th }}$-Century Settlements in the Region of the Central Part of the Hungarian

Little Plain and the Danube Bend

Szabolcs Balázs NAGY

Noble Residences in the $15^{\text {th }}$ century Hungarian Kingdom - The Castles of Várpalota,

Ujlak and Kisnána in the Light of Architectural Prestige Representation

Ágnes KollátH

Tipology and Chronology of the early modern pottery in Buda 


\title{
Rural Society, Agriculture and Settlement Territory in the Roman, Medieval and Modern Period Pilis Landscape
}

\author{
Bence Simon \\ Institute of Archaeological Sciences \\ ELTE Eötvös Loránd University \\ simon.bence@btk.elte.hu
}

\begin{abstract}
This study presents how the scientific results of economic geography can be useful in explaining and deepening our understanding of the settlement pattern, village territory or land-use regarding the Roman, Medieval and Modern period Pilis landscape. Through ordinary comparison and GIS-based investigations the relationship of the studied periods is at the paper's focus. In the last part, the study introduces a method with which the origins of the present-day administrative boundaries can be explored in a new way.
\end{abstract}

\section{Subject and goal}

Archaeology and all human studies, which are trying to reconstruct past events, must face the fact, that available information is limited. ${ }^{1}$ The effects of this problem can be alleviated if one avoids interpreting any human culture isolated, without a reference to other time periods. To highlight tendencies and explain various developments in history, a comparative method was developed in social and economic sciences. ${ }^{2}$ Comparison can also be effectively employed in settlement network and site catchment analyses and it is also available to illuminate the economic and social background of a past society. ${ }^{3}$ Nonetheless, the present paper is not using comparative methods as sociologists and economists do, it is only trying to comprehend objective regularities/irregularities between historic periods focusing basically on human behaviour. From this perspective the aim of the present study is to point out the relationship between rural society, agriculture and settlement territory in different historic periods in the vicinity of modern-day Budapest (Hungary). The proposition of my paper is that rural society and primary cultivation practices affected the land-use and territory of the rural settlements.

\section{Historic periods and the study area}

From a human perspective, the Danube-region in the area of present-day Budapest (Hungary) was important throughout the course of history. In the Iron Age a Celtic oppidum, in the

1 This paper is part of the "Római és újkori tájhasználat viszonyának elemzése térinformatikai módszerekkel a „Pilisi-hegyek” és „Pilisi-medencék” elnevezésü kistájak területén” research project, supported by the ÚNKP18-3 New National Excellence Program of the Ministry of Human Capacities.

2 Tомка 2005. This method is rooted in the view of economic historians, who assume that the laws of economics were known and practiced throughout the course of history in all human societies (HoBson 2014, 13).

3 Most of these archaeological studies are in a way linked to W. Christaller's 'Central Place Theory' (CHRISTALLER 1933), which is using economic spatial theory in the sense of least effort for maximising profit and analyse settlement hierarchy and the structure of settlement patterns (Cf. VIONIS - PAPANTONIOU 2019, 4). 
Roman period the governor's seat, Aquincum and in the Middle Ages one of the royal seats of the Medium Regni were situated here. Besides these obvious central places, ${ }^{4}$ their hinterlands ${ }^{5}$ are also worth being investigated, as they can help us understand past economies and reflect on our present settlement network. As I will address in the subsequent chapter, the general circumstances of the economic and social system were quite alike in the Roman, Medieval and Modern periods. Thanks to the first Hungarian population census ${ }^{6}$ and historical maps, the most information is available of the Modern period, but it has also relevance to the Medieval and somehow to the Roman period. Therefore, this study will be dealing with the $1^{\text {st }}-3^{\text {rd }} \mathrm{c}$. Roman, the late Medieval $\left(13^{\text {th }}-16^{\text {th }}\right)$, and more generally the end $17^{\text {th }}-19^{\text {th }} c$. Modern period.

To provide a more-or-less complete view of the periods mentioned above, the studied region of the paper is an archaeologically well-documented area near Budapest (Fig. 1), ${ }^{7}$ extending to $132 \mathrm{~km}^{2}$. Although the research area is defined along modern settlement territories, it mainly corresponds to two physical geographical microregions. ${ }^{8}$ The natural confines are the Danube to the East, the Buda Hills to the South, the Pilis Mountains to the West and North-West, and the Visegrád Mountains to the North. The heterogenous physical landscape assured that results would be more independently and generally interpreted.



Fig. 1. Research area of the study.

4 They are economic and administrative central places.

5 In this paper by the term hinterland, I mean the area populated by rural settlements, which is connected to the city through social and economic networks. This is a beneficial system for both the central place, which exploits the resources from its controlled area to sustain its economy, and the hinterland, which was in turn offered services. Cf. Christaller's Provision Principle cited by: BintLiff 2002, 215.

6 ÖRI 2002.

7 During the last decades of the $20^{\text {th }} \mathrm{c}$. the region from Budapest westwards was systematically surveyed and its results were published in two volumes. HoRvÁth et al. 1979; DinnYés et al. 1986.

8 DöVÉNyi 2010. 


\section{Settlement territory and agricultural production}

To understand the relationship between rural society, agriculture and settlement territory, some known, but in archaeology not widely applied rules and tendencies must first be introduced. This is necessary, as when they are confronted with the archaeological reality in the next chapter, they will reveal, that in the background the same forces - i.e. agricultural production in connection with travel constraints - governed and shaped the territory of villages in all studied ages. These forces are still shaping our culture and their heritage is still detectable today.

It is trivial that a human person's activities are bound by physical space and this is no otherwise in communal operations either. These operations manifested in the rural economic activities of any Roman, Medieval and Modern period villages ${ }^{9}$ can have a great effect on the settlement network and the human-shaped environment. ${ }^{10}$ Although the relationship between distance and settlement network is long known and studied in archaeology, ${ }^{11}$ the territory of villages got only minor attention in the past. ${ }^{12}$ The simple reason for this, is that territorial reconstruction is also in connection with settlement hierarchy, ${ }^{13}$ which can be more easily defined in case of the higher levels, i.e. towns and cities. ${ }^{14}$

From an archaeological point of view, settlement hierarchy can be problematic, because one must first define the nature of the hierarchy (i.e. administrative or economic) and then elaborate a certain method to connect the archaeological information to the studied type. This uncertainty can be resolved when hierarchical studies use the observations of economic geographers. The most important one is, that there is a tendency towards spatial regularity on the different levels of the settlement hierarchy. ${ }^{15}$ Besides this, the Provision Principle of W. Christaller states, that any of the settlements on the different levels can be treated as a centre of a territory, which nourishes it. ${ }^{16}$ In this sense, on the hierarchical level of villages, the location of the sites would show a regular pattern, in which these settlements should be treated as minor territorial centres. ${ }^{17}$

As human mobility did not change significantly until the industrial revolution, travel constraints operated the same way in all ages, which makes it possible to define the distance, which confined the direct economic reach of a certain settlement. ${ }^{18} \mathrm{M}$. Chisholm in his sum-

9 The settlements in the studied periods are nucleated settlements, i.e. villages, in a sense that they consist of multiple dwellings, and economic units operating at the same place and time. The settlements can only bear minor administrative function. Cf. CHISHOLm 1979, 60.

10 According to the 'Isolated State' theory of J. H. von Thünen (von THüNEN 1826), the ideal system of land-use is primarily governed by 'economic distance' as it is formulated by M. Chisholm (Chisholm 1979).

11 On the applied methods (e.g. cost distance, least-cost path, site catchment analyses) in general see: WHEATLEY - Gillings 2002, 133-147.

12 E.g. demes territories of classical Attica (2-3 km radius): Bintliff 2012, Fig. 8.3, 216-217; Hungarian early Medieval village territories (2,5-3 km radius): BÁLINT 2017.

13 Ducke - Kroefges 2008, 245-246.

14 Roman Aquincum: Simon 2019; late Medieval Buda: Kubinyi 1975, 23-25, 2. ábra. Generally, on Roman and Medieval cities see: BintLIfF 2002.

15 Bintliff 2002, 216.

16 BintlifF 2002, 215.

17 Beyond the definition, regarding M. Chisholm's opinion, villages can also be theoretically considered as J. H. von Thünen's 'Isolated States' (Chisholm 1979, 48). This model can basically be applied to the land-use of Modern period villages (Pilisszántó, Békásmegyer) in this paper. See Fig. 6.

18 This distance, in case of the Roman town Aquincum or the Medieval Buda, which were at the top of settlement hierarchy, is around 18.5 and 17 km respectively (Simon 2019, 199; Kubinyi 1975, 23). 
marizing work on rural settlement and land use, verified the direct relationship between gross/net income and distance from the dwelling place (i.e. village) in a traditional agricultural setting. ${ }^{19}$ As economic rationality is anticipated from any farmer, the territory of a village is likely to have been adjusted to the ideal distance determined by agriculture. Based on $\mathrm{M}$. Chisholm's results, the maximum distance of a plot from a dwelling is between 3-4 km away, and the sustainable is somewhere between 1 to $2 \mathrm{~km} .{ }^{20}$ This proposition especially holds true to farmers intensively cultivating small and dispersed plots. ${ }^{21}$

The production of the smallholders basically concentrated on sustenance as the lack of capital and access to land limited their economic options. ${ }^{22}$ The result of this was, that peasants tried to extract the most from the land they possessed by intensifying production. ${ }^{23}$ The use of intensively and extensively cultivated plots can be significantly different. From an archaeological point of view, the distinctive character of intensive cultivation is, that it employs mainly manpower and hand tools. This way gardening is the primary mode of cultivation, which generates high yields on a small scale with low surplus. In contrast, ploughing with animals and fallowing is the extensive way, which produces relatively low yields, but large surplus. ${ }^{24}$ As villages are mainly the settlements of smallholders, intensive cultivation must have been the primary way to cultivate the land. ${ }^{25}$

\section{Villages and society in the Pilis landscape}

\section{Roman period $\left(1^{\text {st }}-3^{\text {rd }} c.\right)$}

Archaeology possibly possesses the most information on the rural population of Pannonia from the area around Aquincum (Óbuda, Hungary). This is basically the result of the abundant epigraphic material and the extensive excavations conducted in or near the Hungarian capital. ${ }^{26}$ The Roman rural inhabitants of the research area were predominantly the descendants of indigenous Celtic Eravisci, who are archaeologically attested in funerary inscriptions ${ }^{27}$ and a wagon burial ${ }^{28}$ in the territory of the research area (Fig. 2). Although, these grave monuments

19 Chisholm 1979, 54-59.

20 Chisholm 1979, 73.

21 Chisholm 1979, 57.

22 ERDKAMP 1999, 562.

23 Intensification means, that more labour and time is spent on a unit of land (DANIELISOvÁ 2015, 110). In this paper cultivation will be in focus, but also livestock farming was a way to intensify the exploitation of the land (Chisholm 1979, 28). Labour intensity in cultivation always depends on the local climate and environment. For example, in some regions of Spain, wheat is more labour-intensive, than olives or vine CHISHOLM 1979, 64-65, 73).

24 Halstead 1995.

25 This does not exclude extensive agricultural practices, both ways must have been present in a village's environment.

26 In Budapest: Bínó 2017, Kat. 18, 22, 23. Excavations conducted near Budapest were summarized in: OTTOMÁNYI 2014.

27 The Celtic origin of the Eravisci is reflected in the names on the gravestones discovered in the research area: Avvo (Fig. 2, 6; RIU 3, 934; Lupa 3122; visit: http://lupa.at/), Atta (see the gravestone of Avvo), Eburo (Fig. 2, 7; TitAq 609; Lupa 2870), Matiata (Fig. 2, 3; AE 1986, 583; Lupa 3134), Nemoratta (Fig. 2, 5; RIU 3, 942 ; CIL 3, 10571; Lupa 710), Otiorix (Fig. 2, 2; RIU 3, 944; 3133), Tutuus (Fig. 2, 1; RIU 3, 947; CIL 3, 10573; Lupa 711) and Ve[---]rienda (Fig. 2, 4; RIU 3, 948; Lupa 3136). Next to this, the items of the traditional women's costume - the fibulae, the torques and headwear (Csontos 1999, 163, Pl. I. 3 - Pilisszántó) and astral symbols (gravestone of Nemoratta) are also recognisable on these tombstones.

28 The wagon burial was uncovered near the Csillaghegy. Preliminary report of the unpublished excavation: https://mnm.hu/hu/cikk/romai-kocsi-tulvilagra. 
and luxurious burials refer to the wealthiest and Romanised top-layer of the rural society, the dominance of the civilian vici in the $1^{\text {st }}-3^{\text {rd }} \mathrm{c}$. AD confirms ${ }^{29}$ that the "invisible" and broader social stratum in the rural area also comprised of smallholders with Celtic ancestry. This created the frame, which lead to the evolution of organic settlements in the Roman age Pilis landscape.

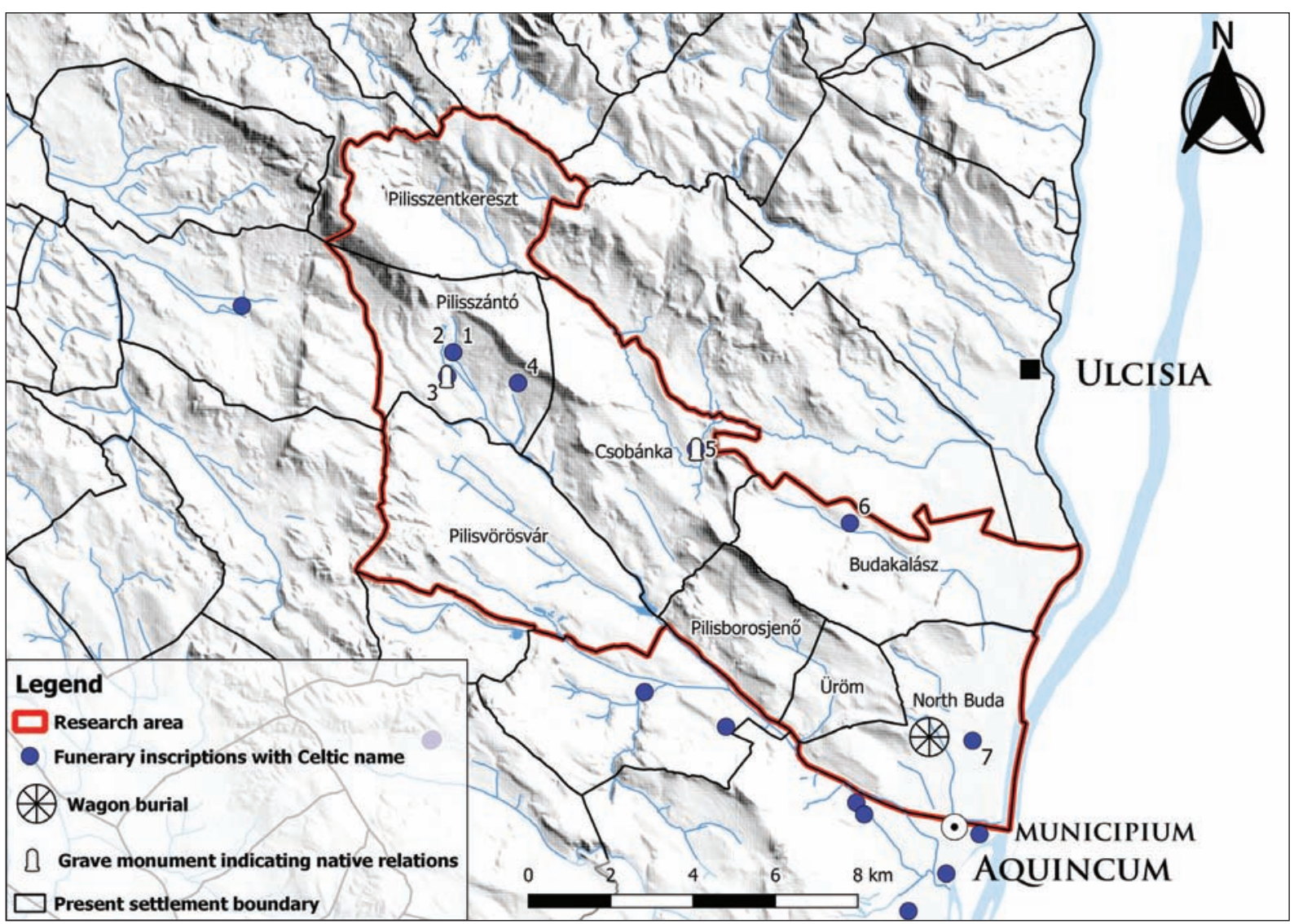

Fig. 2. Roman rural society and their archaeological assemblages.

Next to the Romanised native peasants, veterans and soldiers were also present in the rural sphere. Around Aquincum the most tombstones mentioning military persons from the $1^{\text {st }}-3^{\text {rd }}$ c. AD, can be found in, or in the proximity of the study area. ${ }^{30}$ Many of these soldiers had Celtic names or names indicating native origin and all of them were soldiers of the legio II Adiutrix stationed in Aquincum. Their career cannot be separately studied from the local aristocracy's, as most of the time they probably overlapped. ${ }^{31}$ However, the studied area had stronger connections with the army and a wealthy Eraviscan aristocracy was less prominent in these villages. ${ }^{32}$ This does not change the fact, that veterans and families of the soldiers had probably the most influence in the vici, where they were possessors of middle estates. ${ }^{33}$

29 Sz. Bíró observed, that the first native-style villages (vici) sprung up and dominated regions around Aquincum (Óbuda, Hungary) and Sirmium (Sremska Mitrovica, Serbia), where the indigenous population remained strong in numbers and their central places survived until the Roman occupation (Bíró 2017, 277). In these areas, large estates and villae rusticae were absent even in the $3^{\text {rd }}$ c., only the so called "villa settlements" with multiple stone buildings became typical (Bínó 2017, 208).

30 Besides the common soldiers, this is emphasized by the epigraphic material of high-ranking officers (SImON 2019, 52-53, 19. ábra).

31 Mráv 2013.

32 Cf. note 31.

33 AlfÖLDY 1959. 




Fig. 3. Roman villages of the research area.

Most of the civilian vici in the area were loosely structured, unplanned settlements with only a few Roman-style buildings. ${ }^{34}$ This way a civilian vicus can comprise of many archaeological sites, still forming one social and economic unit. ${ }^{35}$ There are six identifiable vici on the territory of the research area (Fig. 3), ${ }^{36}$ but excavation was conducted only in Pilisszántó, where a stone building with heated terrazzo-floor was unearthed in $2000-2001 .^{37}$ Although, most of the information originates from field-walking, based on the infra- and interprovincial pottery and traces of stone building material, their identification seems quite certain. ${ }^{38}$

Medieval period $\left(13^{\text {th }}-16^{\text {th }} c.\right)$

Based on the results of the recent rescue excavations, Árpádian Age (1000-1301) villages could comprise of multiple, sporadic sites, forming one loosely structured settlement, just as in the case of the Roman age vici. ${ }^{39}$ This is reflected in the charters, as since the reign of Stephen I. (1000-1036) these medieval villages were named villae mostly together with their borders, which not only meant the inner plots of the settlement, but also the whole territory of the

34 The vici in the region were mostly defined as surplus producing (Versorgungssiedlung) and subsistence villages, which were not organized settlements (Bíró 2017, 182-193. Abb. 183, 185). The expression 'vicus' also and foremost signified an administrative and so an economic sub-unit of the territorium of a Roman city (KovÁcs 1997, 49-51).

35 Cf. Simon 2019, 176-177. This comprehension is also valid on Árpádian Age villages. Cf. note 40.

36 See the catalogue of Roman villages (RCat).

37 Kocsis - Prohászka 2003.

38 On the method of identification see: Simon 2017, 275-279; Simon 2019, 169-184.

39 RÁcz 2014, 167-171. 
legally, socially and economically connected community..$^{40}$ In the first half of the Árpádian Age, except for the highest members of the social order (i.e. royal court, clergy), artisans or traders,${ }^{41}$ the whole spectrum of the society lived and worked in these organic settlements. ${ }^{42}$ Based on the charters, there must have been differences between the inhabitants of the villages in wealth and legal status, but this is not reflected in the archaeological material. ${ }^{43}$ The reason for this is, that until the $13^{\text {th }} \mathrm{c}$. the income of the different social strata of the rural society was based on agriculture and animal husbandry. ${ }^{44}$

During the $13^{\text {th }}-14^{\text {th }}$ century's economic, agrotechnical and social transformation, a legally unified peasantry ${ }^{45}$ and the first medieval nucleated villages evolved. ${ }^{46}$ In this period the basic units of agricultural production were the peasants' plots, in which system the residential area and the outer fields became clearly detached. ${ }^{47}$ There was also a change in the living standards, as pit-houses were gradually substituted by peasant houses with two or three rooms, and became general by the end of the $14^{\text {th }} \mathrm{c}^{48}$ The nucleation of the settlements also regulated the system of the land-use and indirectly the boundaries of a village, as the location of peasant-dwellings became permanent.

After the Mongolian invasion (1241-1242) $)^{49}$ the landscape was gradually populated with villag$\mathrm{es}^{50}$ and by the end of $14^{\text {th }} \mathrm{c}$. the Medieval settlement network already reached the peak of its development and survived until the Ottoman rule (Fig. 4). However, there is not much information about these settlements, as excavation was only conducted in the area of Óbudaörs. ${ }^{51}$ Although, this does not allow us to reconstruct the inner topography of the individual settlements, their location can be verified with the careful examination of the charters and the location of their parish churches. ${ }^{52}$ The latter is important, as churches even before the $14^{\text {th }} \mathrm{c}$. were the most obvious human-made orientation points, which were most of all the cultural centres of the village community. ${ }^{53}$ This way their location could be the starting point of my cost distance analyses below.

From the $14^{\text {th }} \mathrm{c}$., there is already some precise information about the demography of Medieval Hungary. The most important sources in this regard are the papal tithe registers of the 1330's

40 RÁcz 2019, 141, 145.

41 Laszlovszky 2018, 88.

42 On the legal stratification and evolution of the society in the Árpádian Age see: Bolla 1983.

43 Some attempts to differentiate the various social strata of Árpádian Age population: LAszLovszky 1991; TAKÁCs 2015. The building material, the ground-plan and the construction method of the semi-subterranean pit-houses' does not allow any hierarchical distinction in the villages or between regions (RÁcz 2019, 149). Pit houses were also typical in royal or ecclesial centres (TAKÁcs 2015, 178).

44 RÁcz 2019, 151.

45 SzÜCS 1981; BOLla 1983.

46 PÁlóczi Horváth 2006, 358; TAKÁcs 2015, 182.

47 PÁlóczi HoRváth 2006, 358.

48 PÁlóczi Horváth 2006, 358; TAKÁcs 2015, 183-184; On the evolution of the late medieval houses see: MESTERHÁZY 1991.

49 The earliest Hungarian settlements are known from the territory of Pilisvörösvár and Csobánka (DINNYÉs et al. 1986, 6. térkép). On the early Hungarian settlement history of the territory of Buda see: NAGY 1975, 209-216.

50 In the research area there are 17 recorded medieval villages and 15 others as their nearest neighbours. See the catalogue of Medieval villages (MeCat).

51 Havas et al. 2017, 43-48.

52 E. Tari summarized the information regarding the Medieval churches of the villages mentioned in this paper (TARI 2000).

53 Churches were the central places of villages, and even after their abandonment or a change in the settlement pattern they had an influence on the boundaries (STIBRÁNYI 2017). 


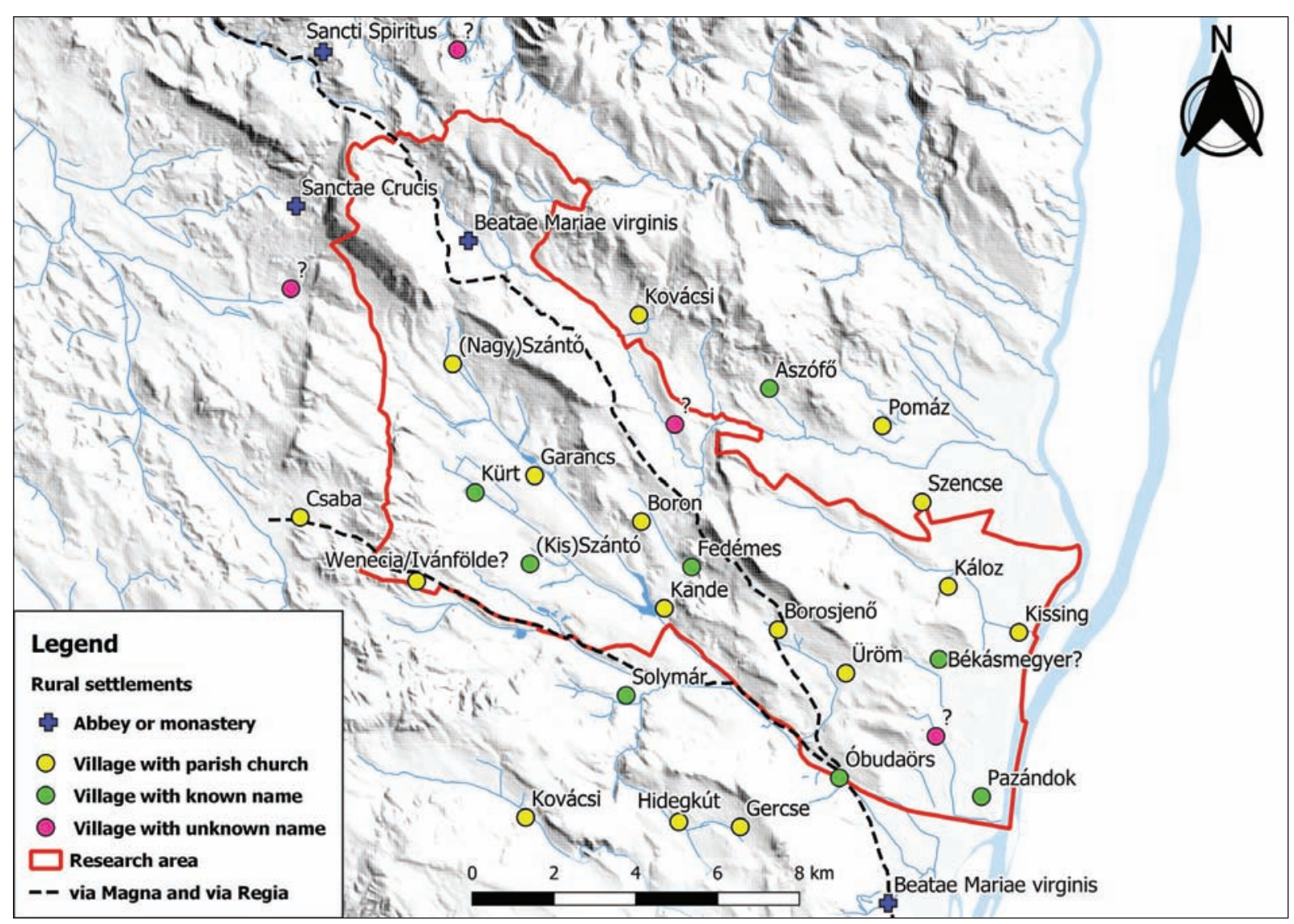

Fig. 4. Medieval villages of the research area.

and the sum of the royal tax censuses of the 1490 's,${ }^{54}$ which still permit only a careful reconstruction of the society. As these sources were concerned only with those, who were obliged to pay taxes, the number of the peasantry is the best known. Although, many other problems arise about the reconstruction of the other strata of the society, it seems certain, that peasants constituted the great majority of the kingdom's inhabitants, ${ }^{55}$ which was especially true in case of the villages. The wealth of the peasantry, which influenced land-use and the way of cultivation is hard to assess, only the increasing economic stratification seems certain from the late $15^{\text {th }} c^{56}$

Modern period (end $17^{\text {th }}-19^{\text {th }}$ c. $)^{57}$

After the Ottoman rule the abandoned villages were systematically or naturally repopulated ${ }^{58}$ by Hungarians, Germans, Serbs and Slovaks and the settlement network we know today consolidated. From the end of the $18^{\text {th }} \mathrm{c}$. the ethnic composition, the population and the land-use of the villages' is well known, as they were documented by historic maps and Joseph II's population census. The distinctive aspect of the Modern period's rural society in the area is, that only a few members of the nobility lived in the villages and a rich peasantry was also not dominant in numbers (Tab. 1). ${ }^{59}$ The settlements were mostly inhabited by cottars (Lat. inquilini,

54 Kubinyi - Laszlovszky 2018, 50.

55 Kubinyi 1996, 152, I. táblázat.

56 LaszlovszKy 2018, 111.

57 The detailed reconstruction of the social and ethnic history of the region is out of scope of this study. The chapter will focus on the correlations between economy, land-use and society.

58 FERENCZI - LASZlovsZKY 2014, 107.

59 In the first population census rich peasants had at least a quarter of a plot (Hung. telek): ŐRI 2003, 161. 
Hung. zsellérek) and slaves, who intensively cultivated the land around the settlement. It is important to point out, that corresponding to the results of M. Chisholm's cited publication, P. Öri could statistically prove the connection between land-use and the social composition of the villages. ${ }^{60}$ According to his work, villages can be classified into two groups. In the first, rich peasantry was significant and the proportion of extensively cultivated ploughland was high. In the second, where the number of rich peasants was lower than the average, labour intensive viticulture and animal husbandry was more important (Tab. 1). ${ }^{61}$ Based on the abovementioned sources, the rural landscape in the Modern period was dominated by villages, whose land-use was affected by the economic/social composition of their inhabitants.

\begin{tabular}{|c|c|c|c|c|c|c|c|c|}
\hline Village & $\begin{array}{l}\Delta 0 \\
\stackrel{0}{\Xi} \\
\Xi\end{array}$ & 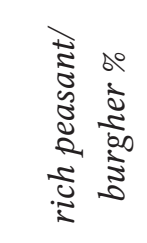 & 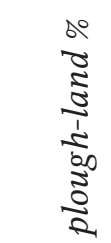 &  & 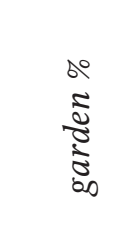 &  & 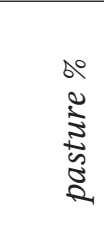 & 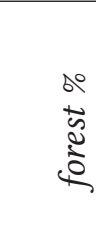 \\
\hline Pilisszentkereszt & 0 & 19.7 & 12.4 & 2.2 & 0.7 & 4.7 & 2 & 77.9 \\
\hline Pilisszántó & 0 & 24.9 & 41.4 & 5.2 & 0.7 & 5.2 & 0 & 47.5 \\
\hline Pilisvörösvár & 0.6 & 33.5 & 57.9 & 2.5 & 0.8 & 9.8 & 2.8 & 26.2 \\
\hline Csobánka & 0.2 & 27.3 & 43.7 & 7 & 0.9 & 3.2 & 11.2 & 34 \\
\hline Pilisborosjenő & 0 & 26 & 38.6 & 9.1 & 2.7 & 0.5 & 25.6 & 23.5 \\
\hline Üröm & 0 & 32 & 50.9 & 10.1 & 1.9 & 1.1 & 35.9 & 0 \\
\hline Budakalász & 0 & 41.9 & 47.5 & 3.8 & 0.8 & 6.3 & 13.4 & 28.3 \\
\hline Békásmegyer & 0 & 11.8 & 43 & 13.8 & 3.8 & 12.6 & 26.8 & 0 \\
\hline
\end{tabular}

Tab. 1. Society and land-use in the Modern period Pilis landscape (source of data: ÖRI 2003, App. IV).

\section{Intensive cultivation and villages}

Intensive and extensive cultivation were practiced side by side in all studied periods, but growing labour intensive vegetables, fruit and especially grapes was probably the result of cultural impact and the need of the nearby urban centres. In the Roman period, the growing military and urban population in the area of Aquincum was the cause of agricultural transformation. Garden vegetables were already present at the pre-Roman settlements in the area, ${ }^{62}$ but fructi- and viticulture seem to have Mediterranean origins in Pannonia Inferior, ${ }^{63}$ which were introduced by the Roman immigrants. Besides the archaeobotanical samples, iron tools ${ }^{64}$ and other archaeological features provide secondary evidence to intensive cultivation, like the wine-growing pits unearthed on the territory of the former vicus at Csúcshegy. ${ }^{65}$

60 The author did not explicitly explain the connection between economic/social status and land-use in his published doctoral dissertation.

61 ÖRI 2003, 179-181.

62 Gyulai 2010, 146, 155.

63 DÁlnoki 2009, 146-148, 149-150; Gyulai 2010, 157-158; MANEN et al. 2003.

64 Hoes, spades and pruning knives can be listed among the tools which can be connected to intensive cultivation. On the Pannonian iron tools see: RupNik 2014. On the distribution of the iron tools in the area see: Simon 2019, 39. ábra.

65 Havas 2011. 
As Roman villages were the sub-units of the urban territorium, the administration must have defined the territory of the settlements, which stabilized their geographical position and thus contributed to the nucleation of the households. There is no direct information about the land-use system in the Roman period, but the identified square parcels in the Pannonian vici suggest, that an industrial and agricultural area can be anticipated immediately beside the houses. ${ }^{66}$ As distance from the dwelling-place affected the net income from production, vegetables, fruit and vine were probably grown in the mentioned square parcels.

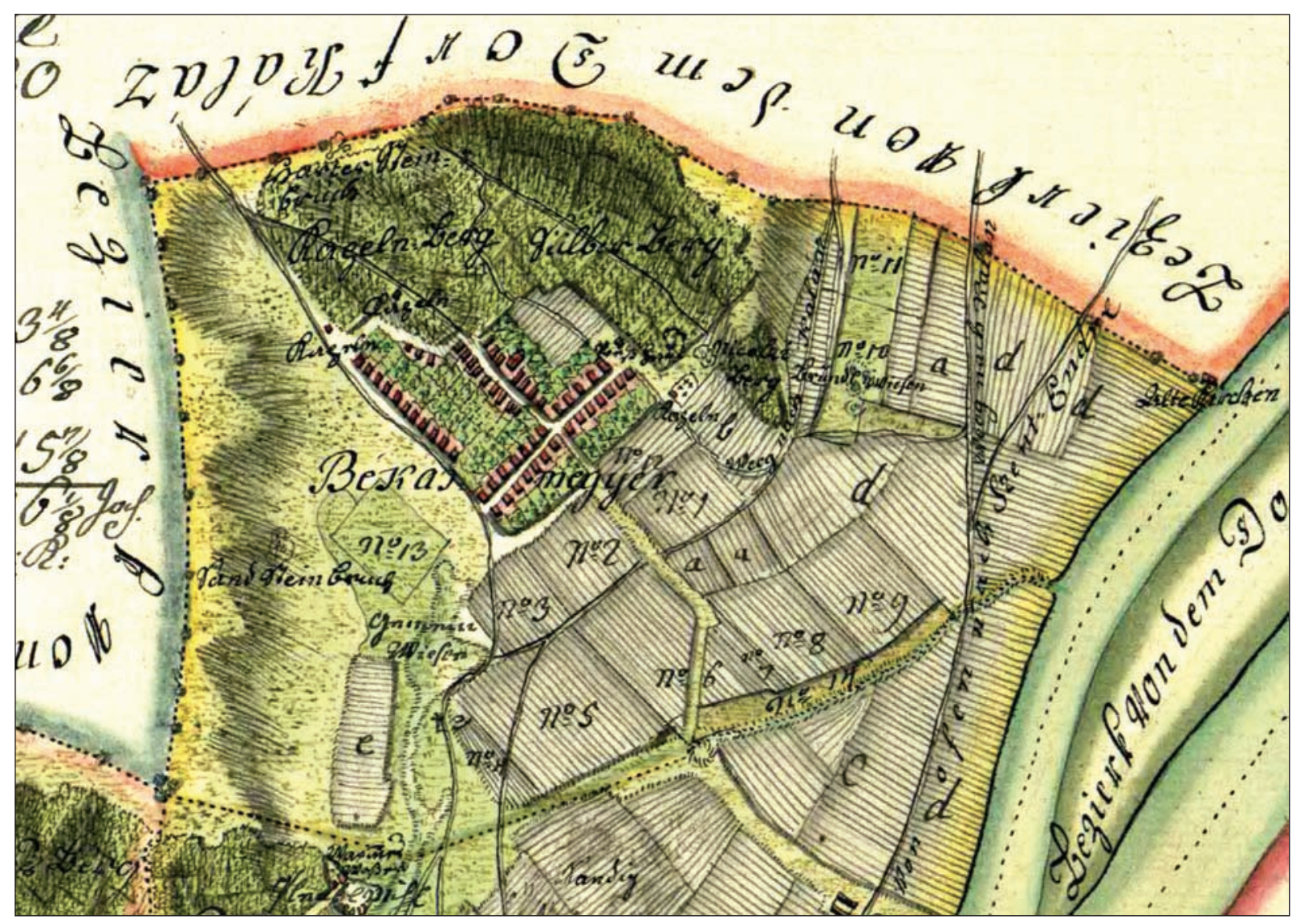

Fig. 5. Detail of the historic map of Békásmegyer from 1778 (MNL OL, S11 No. 830:69).

The transformation of Medieval agriculture from the $13^{\text {th }} \mathrm{c}$. was driven by internal and external factors and cultivation gradually became more intensive. Like the transformation in the Roman period, the extensive growing of fruit, legumes and vine was introduced by newcomers, like the clerical-monastic orders and foreign settlers (hospes). ${ }^{67}$ The newly-established church organization and the laws banning removal had also part in the establishment of the Late Medieval land-use and village network which was already mentioned above. ${ }^{68}$ The land-use system survived the Ottoman rule and intensive cultivation was reinforced by the growing internal market and the Austrian central lands' need for agricultural surplus. ${ }^{69}$ The Modern period land-use system was documented on historical maps from the $18^{\text {th }} \mathrm{c}$., which can also be

66 Bínó 2017, 67.

67 LASZlovszKy 2018, 94-95.

68 LASZLOVSZKY 2018, 93.

69 FÜLÖP - HOZÁK 2014, 2. 
handled as a retrospective illustration of the late Medieval agricultural utilization (Fig. 5). ${ }^{70}$ On the internal plot, mostly immediately behind the house lay the kitchen garden, where vegetables and fruit were grown, while ploughland was confined to the open-field area. ${ }^{71}$ The first data on the Medieval villages of the research area originate mostly from charters mentioning vineyards in the $13^{\text {th }}-14^{\text {th }}$ c. $^{72}$ These plantations were probably near the settlements (Cf. Fig. 5). Despite the fact that they could be in possession of persons outside the villages, ${ }^{73}$ vine needed much labour which was available in the rural settlements. In some cases, when fresh water was needed, vegetables were grown in the open-field along streams (e.g. cabbage-field Lat. cauleta), as it was recorded on the $18^{\text {th }}$ c. map of Pilisszántó (Fig. 6).

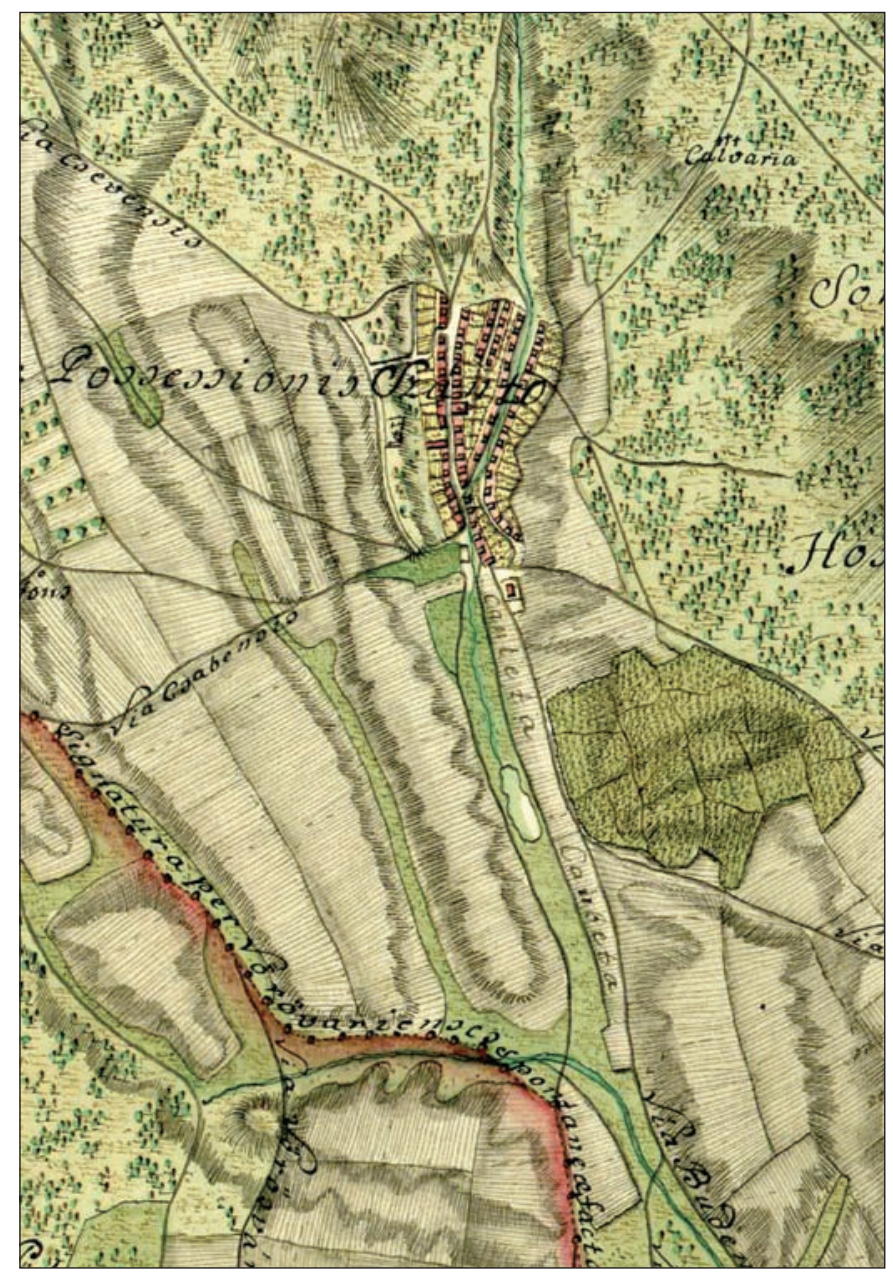

Fig. 6. Detail of the historic map of Pilisszántó from 1767 (MNL OL, S11 No. 830:84).

\section{Settlement network, terri- tories and boundaries in the Pilis landscape}

The abovementioned sources anonymously indicate the importance of gardening, fruit farming and viticulture near the Roman, Medieval and Modern period villages. Distance from the dwellings affected the possibility of growing these labour-intensive crops, therefore it must have formed the village system in the studied region. Previous studies on the Roman settlement network in the North-Eastern region of Pannonia revealed that villages, the civil town and the legionary fortress of Aquincum and all camps constitute a regular system. ${ }^{74}$ To study the pattern of the settlement network, I used the nearest neighbour analysis, ${ }^{75}$ which showed that the observed mean distance is $3216 \mathrm{~m}$ between the nearest village neighbours and $3187.5 \mathrm{~m}$, when the military and urban settlements are incorporated. This result can best be compared

70 LAszlovszky et al. 2018, 6.

71 LAsZlovszKy 2018, 105.

72 See the cited literature of (Nagy)Szántó (MeCat. 2), Garancs (MeCat. 4), Boron (MeCat. 7), Kande (MeCat. 8), Borosjenő (MeCat. 11), Üröm (MeCat. 12), Káloz (MeCat. 13), Békásmegyer (MeCat. 15) and Pazándok (MeCat. 17).

73 LASZLOVSZKY 2018, 109.

74 Simon 2017, 280, Fig. 7; Simon 2019, 56-57. ábra.

75 The analysis was performed with the Average Nearest Neigbor analysis of ArcGIS 10.3 (https://desktop. arcgis.com/en/arcmap/10.3/tools/spatial-statistics-toolbox/average-nearest-neighbor.htm) (Cf. SImON 2015, 113 , note 38 ). 
to the suitable distance between the cultivated plot and the dwelling, which does not exceed $2 \mathrm{kms} .{ }^{76}$ Nearest neighbour analysis is statistically significant only if the sample has more than 50 elements, ${ }^{77}$ but it gives much the same observed mean distance $(3127 \mathrm{~m})$, if the Roman settlements in the study area and the ones immediately outside it are investigated.

The Medieval village settlement network was denser ${ }^{78}$ than the Roman, as the observed mean distance between nearest neighbours was $2413.5 \mathrm{~m}$ when the villages with known names and monasteries were analysed, and $2232 \mathrm{~m}$ when all rural settlements were incorporated in the study. ${ }^{79}$ This denser network can be the result of multiple reasons, like the number and the wealth of the village inhabitants, traffic infrastructure or the presence of secondary rural economic units (e.g. manors). It is possible, that Medieval villages had less dwellers as the Romans, which could have housed up to 600 persons. ${ }^{80}$ However, the network of late Medieval churches can best be compared to the Roman settlement pattern, as the mean distance between parish and monastic churches was $2933.5 \mathrm{~m} .{ }^{81}$

The Modern period settlement network was slightly looser than the Roman age's, ${ }^{82}$ as the observed mean distance between neighbouring settlements was $3346 \mathrm{~m}$. This would suggest that for various reasons, the land-use of Roman and Modern villages was more extensive, than Medieval ones, but it is not necessary the case. ${ }^{83}$ The same can be true in case of estimating a mean territory of the settlements, based on the raw data provided by the average nearest neighbour analysis. ${ }^{84}$ Above I referred to the essential connection between distance, settlement territory and the allocation of available resources, but did not deal with the problem of interpreting distance and its relationship to village borders.

An agent translates distance as a cost of movement, therefore it is essential to incorporate the physical characteristics of the landscape in the modelling and the interpretation of historic settlement territories. ${ }^{85}$ For this, a Digital Elevation Model (DEM) was created with the elevation contours and points of the 1:10000 scale Uniform National Mapping System (in Hungarian: EOTR) topographic maps. ${ }^{86}$ These maps also mark the present settlement borders, which were also manually digitalized to compare them with the historic village patterns and their ideal territories.

76 Cf. note 21.

77 Nemes Nagy 1998, 135-141.

78 Settlement density can also be illustrated with Kernel density analysis (Cf. Simon 2015).

79 Four rural settlements were excluded from the first analysis: MeCat. 10, 16, 23, 25.

80 K. Ottományi estimates the population of the vicus in Budaörs between 300 and 600 persons (OtTOMÁNYI 2012, 342).

81 This network seems to be denser, than the parish system in Tolna county, where churches were 3-4 km away from any villages at the most (K. NÉMETH 2011,39).

82 On the Modern settlement locations see the catalogue of Modern settlements (MoCat).

83 Unfortunately, there is no exact information about the cited factors (population, wealth, infrastructure etc.) affecting land-use in the Roman and Medieval period.

84 In the nearest neighbour analyses Euclidean distances were examined, which do not necessarily reflect the human perception of distance on a diverse terrain.

85 In archaeology the creation of Thiessen polygons (WHEATLEY - Gillings 2002, 149-151) is the most common practice to reconstruct the ideal territories of settlements, but they often overlook the problem of the movement penalties on terrain.

86 The digital contours of the research area $\left(132 \mathrm{~km}^{2}\right)$ were acquired at the material costs of the research project from the Government Office of the Capital City Budapest, Department of Geodesy, Remote Sensing and Land Offices. Elevation points and the contours of the broader area were manually digitalized as part of my PhD dissertation (SImon 2019). The DEM was created with the 'Topo to Raster' tool of ArcGIS 10.3: https:// desktop.arcgis.com/en/arcmap/10.3/tools/spatial-analyst-toolbox/topo-to-raster.htm. 
There is no exact information about the boundaries of the Roman and Medieval period settlements, ${ }^{87}$ therefore with GIS their ideal territories were first reconstructed. The reconstruction rested on three assumptions: 1) territories belonging to a village are spatially uninterrupted and continuous, 2) a piece of land belongs to only one village, 3) villages have equal weight in shaping their territories ${ }^{88}$ To integrate the physical diversity of the landscape, a reclassified slope raster ${ }^{89}$ functioned as the cost surface in the study, with which path distance analyses were performed and ideal territories were created.

The former method served to understand, how distance from a certain village shaped the boundaries..$^{90}$ Based on the results of the path distance analysis, Roman villages were about fifty minutes to one hour from the nearest neighbours on foot, and the nearest boundaries were also probably 40 minutes $(3333 \mathrm{~m}$ ) away from the village at the most (Fig. 7). In the thicker Medieval village system, nearest neighbours were forty to fifty minutes far from each other and the nearest boundaries of the villages were 30 minutes $(2500 \mathrm{~m}$ ) away (Fig. 8). These results highlight that it takes nearly twice the energy to reach the neighbouring settlements in a real landscape, than in the Euclidean space. ${ }^{91}$

Settlement boundaries are cultural constructions, therefore they are not equal to ideal boundaries. However, ideal boundaries and territories are available to explore the roots of real ones. To approach the origins of the present boundaries in the research area, we must follow a reverse order in time. Ideal settlement territories, which were calculated the same way as Roman and Medieval ones, cannot be compared to real territories, ${ }^{92}$ as the ideal territory of Pilisszentkereszt, Pilisvörösvár, Csobánka and Üröm are significantly bigger and smaller in case of Budakalász and Pilisszántó (Fig. 9). However, historical maps, which recorded the $18^{\text {th }}$ c. territorial disputes of Pilisszántó, ${ }^{93}$ attest that villages did concern about ideal territories. When the disputed regions are projected on the map, they highlight exactly the areas, where boundaries exceeded or were inferior to ideal territories.

The reason for instable borders and ongoing territorial changes, is that after the Ottoman rule, many late Medieval village territories were abandoned and were divided between, or

87 There is much written information about the borders of Medieval villages from perambulations, but their geographical interpretation can be problematic. E.g. the border of Kande (FERENCZI - LAsZlOvszKY 2014) or Békásmegyer (FERENCZi 2014).

88 This model slightly differs in its basic assumptions from the Xtent model developed by B. Renfrew and E. Level (Renfrew - Level 1979; Ducke - Kroefges 2008, 247).

89 The slope raster was calculated from the DEM and it was reclassified into six classes with the Jenks natural breaks classification method (SIMON 2015, 118). Ideal territories were created with the 'Path Distance Allocation' tool of ArcGIS 10.3: https://desktop.arcgis.com/en/arcmap/10.3/tools/spatial-analyst-toolbox/path-distance-allocation.htm.

90 Based on Tobler's hiking function's walking velocity on a flat terrain $(5 \mathrm{~km} / \mathrm{h})$, distances were converted into minutes in the path distance analysis (ToBLER 1993). E.g. 5000/4 m = $1250 \mathrm{~m}=15 \mathrm{~min}$. On the analysis see: https://desktop.arcgis.com/en/arcmap/10.3/tools/spatial-analyst-toolbox/path-distance.htm.

91 See the results of nearest neighbour analysis, compared to nearest possible boundaries between historic settlements.

92 Present-day settlement boundaries are roughly the same as those of the $18^{\text {th }} \mathrm{c}$.

93 Northern region (1771): MNL (National Archives of Hungary) S11 No. 29/1-2. (https://maps.hungaricana. hu/en/MOLTerkeptar/1419/?list=eyJxdWVyeSI6ICJwaWxpc3N6XHUwMGUxbnRcdTAwZjMifQ); Eastern region (1759): MNL S148 No. 44. (https://maps.hungaricana.hu/en/MOLTerkeptar/38578/?list=eyJxdWVyeSI6ICJwaWxpc3N6XHUwMGUxbnRcdTAwZjMifQ); Southern region (1767): MNL S11 No. 830:84. (https:// maps.hungaricana.hu/en/MOLTerkeptar/2481/?list=eyJxdWVyeSI6ICJwaWxpc3N6XHUwMGUxbnRcdTAwZjMifQ). On the disputed regions on map see: Fig. 9. 




Fig. 7. Path distance analysis on the Roman age rural landscape and ideal settlement territories.

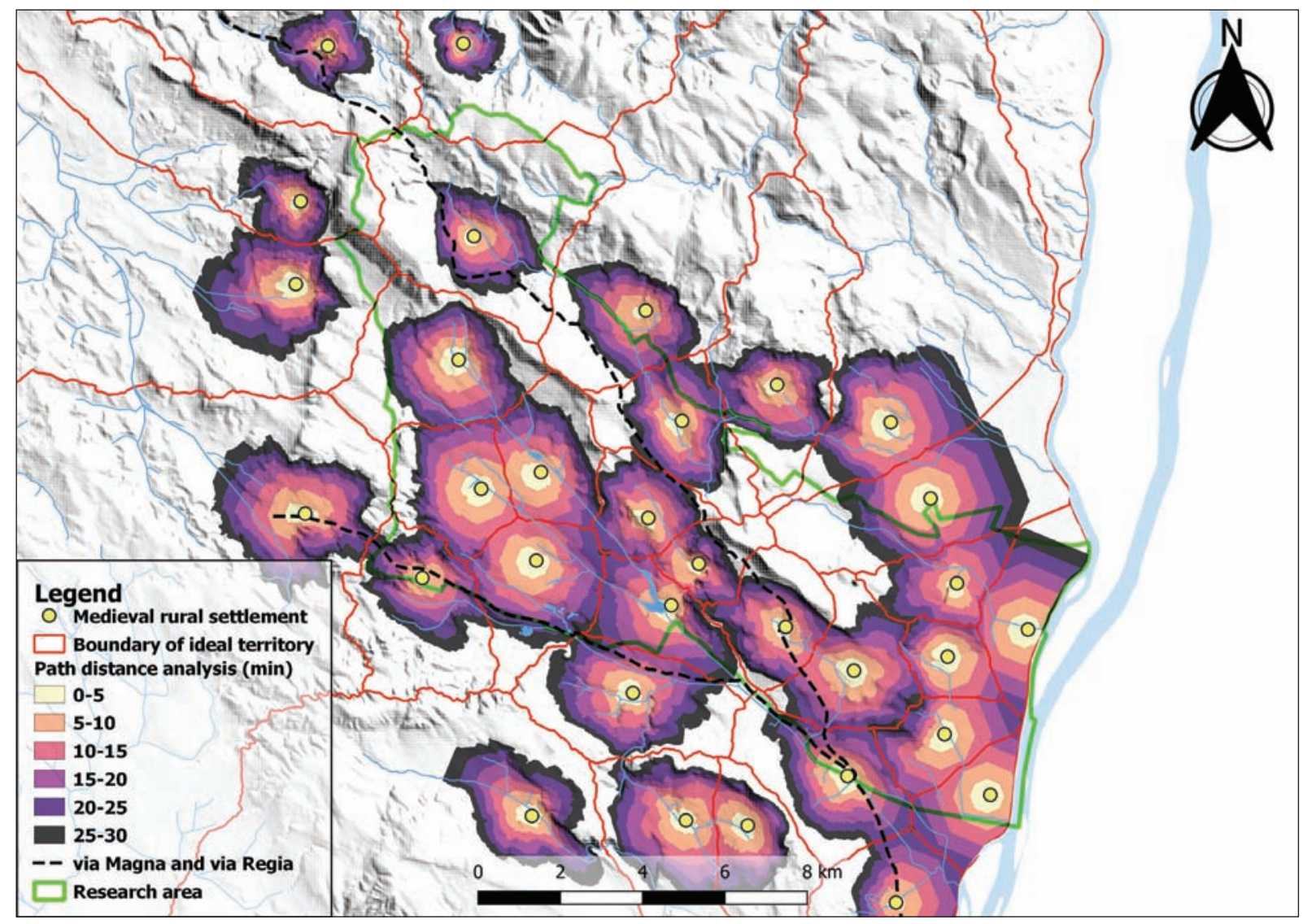

Fig. 8. Path distance analysis on the Medieval rural landscape and ideal settlement territories. 


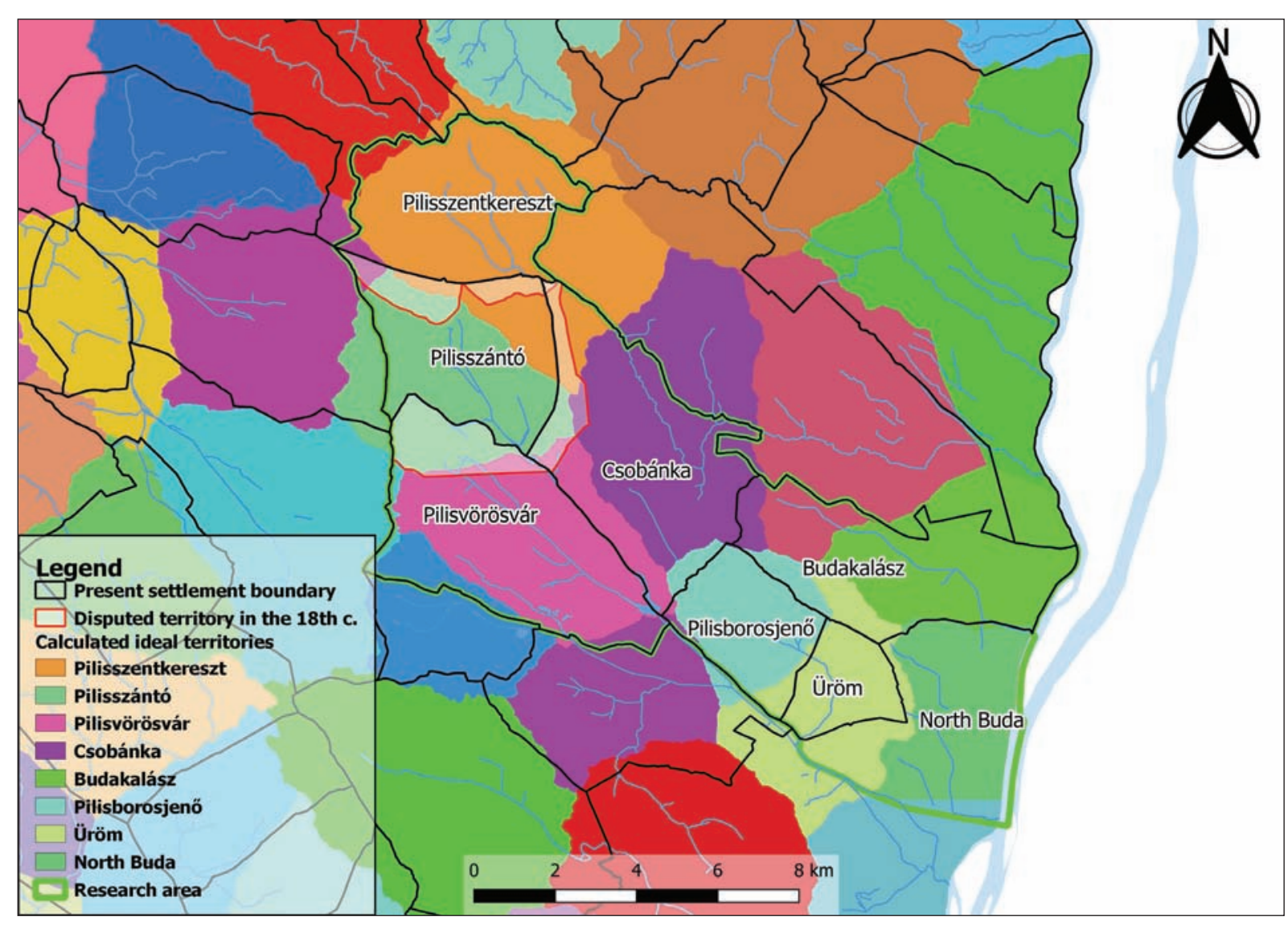

Fig. 9. Present-day administrative boundaries and ideal territories of Modern villages.

were annexed to the repopulated settlements (Fig. 10). The Medieval territory of Kürt and the northern part of Ivánfölde was annexed to Kisszántó (later Pilisvörösvár), just like Aszófő to Pomáz. However, most of the village territories were probably divided between neighbouring settlements:

- Garancs (MeCat. 4) between Pilisszántó, Pilisvörösvár, Csobánka.

- Kande (MeCat. 8) between Pilisvörösvár, Csobánka, Pilisborosjenő, Solymár.

- Fedémes (MeCat. 9) between Csobánka, Pilisborosjenő.

- Kovácsi (MeCat. 26) between Csobánka, Pomáz. ${ }^{94}$

- Szencse (MeCat. 29) between Pomáz, Budakalász.

- Kissing (MeCat. 14) between Békásmegyer/Buda, Budakalász.

With the help of the outlined ideal Medieval boundaries, the possible origin of Modern borders can be exposed (Fig. 11). Boundaries had to be easily recognizable, therefore they were defined along certain natural and artificial landmarks. Based on this, all Modern border-segments can possibly have Medieval origins, which extend near ideal Medieval boundaries and defined along ridges, brooks or major roads.

The present-day boundaries of Pilisszentkereszt are likely to have preserved the abbey's Medieval territorial state. This seems to be certain in the western, northern and eastern section and only questionable in the southern region. In the western and northern region, the bound-

94 The first four were probably already abandoned in the late Medieval period (FERENCZI - LAsZLOvszKy 2014, 107). 


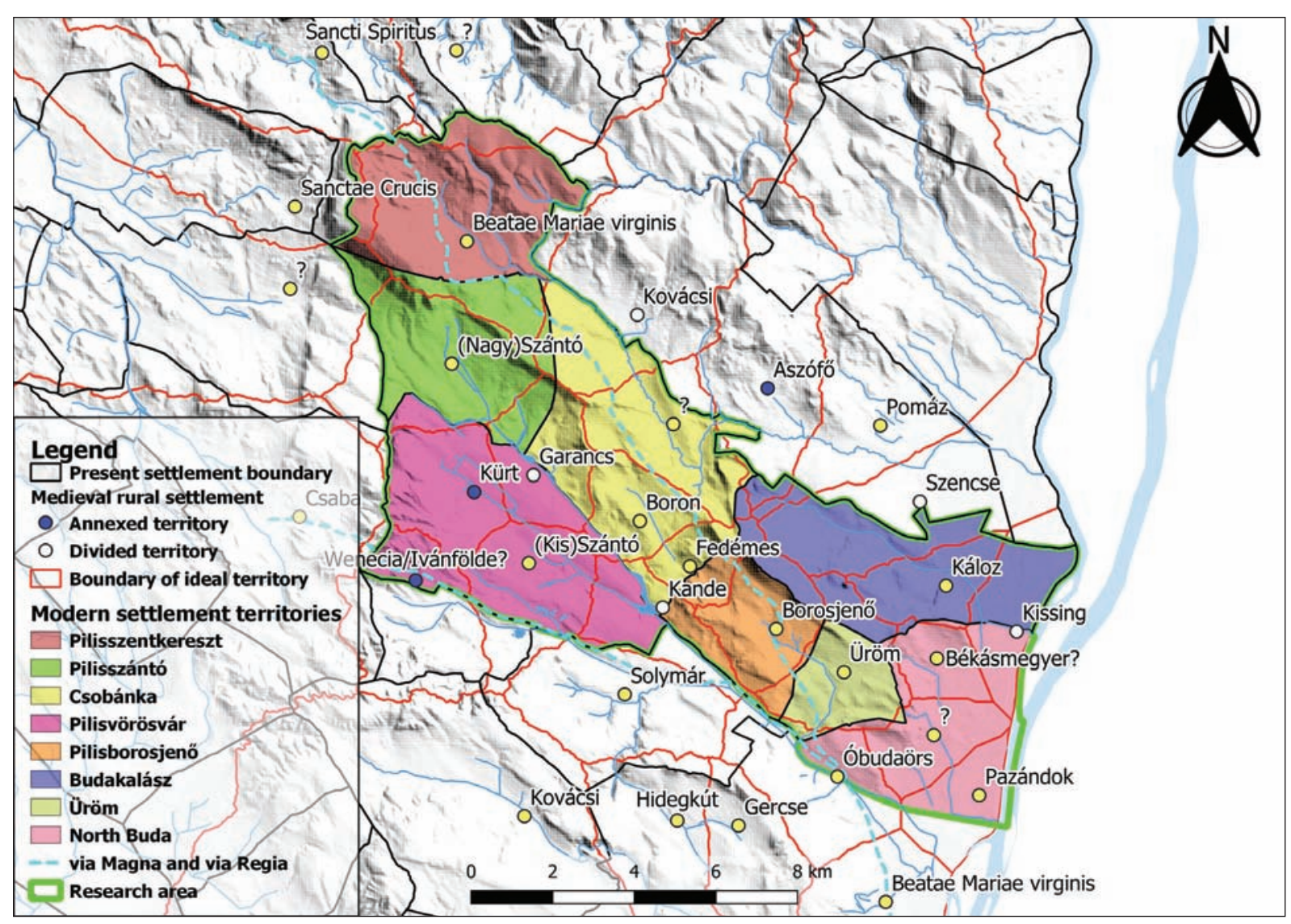

Fig. 10. The relationship of ideal Medieval settlement territories to present-day administrative boundaries.

aries are on the mild slopes from the Nagy-Szoplák and Nagy-Bodzás Hill to the West and the Kis-Szoplák to the North. From here the border runs above the steep slopes and turns south-east at Dobogó-kő. From here it runs along the Hosszú/Öreg-vágás Hill to reach the Bükkös Brook. The eastern border of Pilisszentkereszt follows the Bükkös Brook and heads towards the Szentkút Spring and the rivulet running into the Kovácsi Brook. The present-day southern border of Pilisszentkereszt is partly the course of the Kovácsi Brook and a section of the Medieval via Regia. ${ }^{95}$

Like the north-eastern borders of Pilisszentkereszt, the northern boundaries of Pilisborosjenő and Üröm run along the ridges of the Nagy-Kevély, Ezüst and Kő Hill, which can also indicate Medieval origins. The same applies to the southern border of Uröm, which arrives to the great road (via Magna) in the West, which confines the settlement territory from the South-West. The northern section of the boundary between Pilisborosjenő and Üröm can be compared to the ideal territory's border, but it is different to the South. Maybe the territorial affiliation of this region was not stable, that is why there were many disputes over its possession. ${ }^{96}$ The north-eastern border of Csobánka and the western border of Pilisvörösvár can also be Medieval in origin, as both run on ridges.

95 On the history of the via Regia see: Benkő 2011. The course of the road was drawn based on Hungary's First and Second Military Survey and the paper of Zs. Pető (PETő 2014). The via Magna, which was the main road between Buda and Esztergom, was drafted with the similar method.

96 See the Medieval perambulation from 1355: MNL DL 4503. (Q 332) https://archives.hungaricana.hu/en/charters/47440/?list=eyJxdWVyeSI6ICJKRUxaPSg0NTAzKSJ9. 
Bearing in mind the above-mentioned demarcation customs, I would suppose, that the north-eastern borderline of Üröm, Pilisborosjenő continued to the North-West, along the Hosszú Hill and other ridges to reach the present boundary of Pilisszentkereszt. In the area of Csobánka a section of the via Regia was most probably the Medieval boundary. This would also explain, why the northern border of Boron was not mentioned in the perambulation of the year 1299. ${ }^{97}$

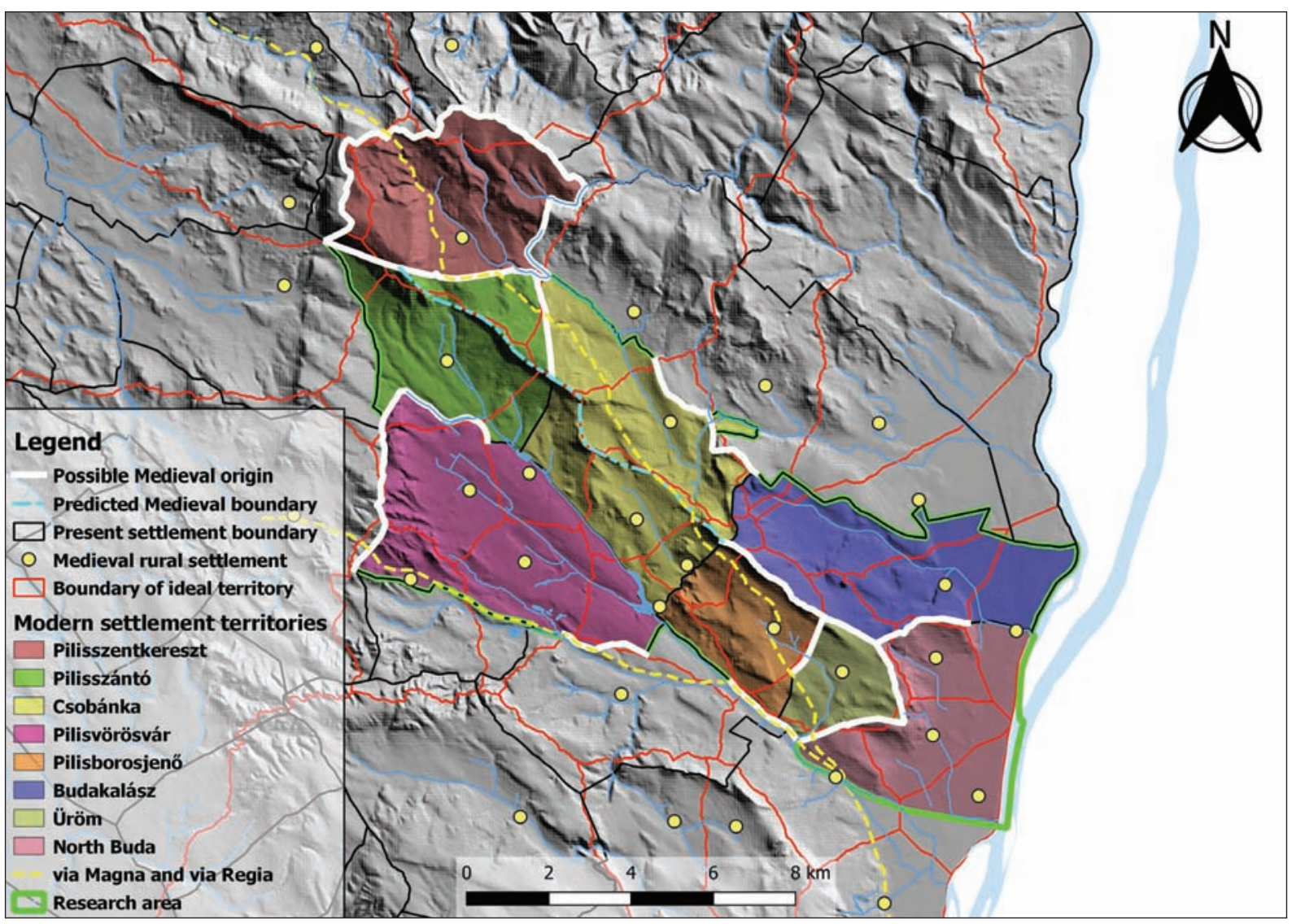

Fig. 11. Modern administrative boundaries with possible Medieval origin.

\section{Conclusion and future goals}

The goal of this paper was to highlight the relationship between rural society, agriculture and settlement territory in the Roman, Medieval and Modern period Pilis landscape. The examined villages were nucleated settlements, which functioned as microregional centres in the direct marketing reach of the given period's regional centre. The broad spectrum of the society lived in these villages, but the population constituted mostly of smallholders, which decisively affected land-use and settlement boundaries.

The main economic profile of the rural sector was agricultural production in which the characters of intensive cultivation could be observed. This type of land-use must have concentrated on the direct vicinity of the dwellings and it is verified through various sources, like archaeobotany regarding the Roman Age, charters of the Medieval period or historical maps recording the situation in the Modern period. Based on these sources we must assume that

97 MNL DL 16746. (Q 332) https://archives.hungaricana.hu/en/charters/14471/?list=eyJxdWVyeSI6ICJTWk89KDE2NzQ2KSJ9 (Cf. FERENCZI - LASZlovszKy 2014, 108). 
beside the extensively cultivated field crops, vineyards and gardens characterized the landuse of the settlements in all studied ages.

The average nearest neighbour analyses revealed, that the Medieval settlement pattern was the densest, the reason of which needs further inquiry. This can be derived from either the wealth, the number of the population, the infrastructure of mobility or simply the moderate economic relations with the regional centre of Buda in the $13^{\text {th }}$ to $14^{\text {th }} \mathrm{c}$. Based on the analyses, the average distance between nearest neighbours did not exceed the distance limit of sustainable intensive cultivation, which is between 3 to $4 \mathrm{~km}$ away from the dwelling. The GIS study highlighted, that the observed distance is actually twice in real space, thus the nearest boundaries of the settlements were established where the threshold distance of sustainable intensive cultivation was reached.

Through generating ideal territories, the study affirmed, that boundaries are cultural constructions and need to be examined together with former periods to find their origins. Modern and contemporary settlement territories are the result of territorial changes after the late Medieval period, during which certain village areas were annexed or divided between the repopulated settlements of the $18^{\text {th }} \mathrm{c}$. The case of Pilisszántó showed, that newly defined territories were still disputed, as ideal territories did matter to the inhabitants of the villages. The Modern settlement boundaries of Pilisszentkereszt, Üröm and Pilisborosjenő showed the closest connection with Medieval ideal territories, which could suggest an earlier origin. The study also predicted a possible Medieval boundary along the ridges from Pilisszentkereszt to Pilisborosjenő.

It needs to be emphasized, that the presented economic and social study, complemented with the GIS-assisted analyses, only contributes to the better understanding of the relationship between rural population, cultivation and village territories and it demands further research into various problems. The main problem is the chronology of the settlement network, which is not robust regarding the Roman and the late Medieval period. This would highlight how the villages evolved in the studied centuries, whether declines or growths could be observed? The other problem is the relationship of ideal territories with real ones, which is not examined with archaeological tools in the Roman Age. This would be problematic regarding the Medieval times, but it may be possible in case of Roman villages. It would be also interesting to confront data derived from Medieval perambulations with ideal territories and Modern boundaries with assumed Medieval origins..$^{98}$ In the future a similar regional study would also provide new data regarding the emerging issues of the relationship between economy, society and human behaviour in various historic periods.

\section{References}

Alföldy G. 1959: Municipális középbirtok Aquincum környékén. Antik Tanulmányok 6, 19-55.

BÁLINT M. 2017: Az Árpád-kori településhálózat rekonstrukciója a Duna-Tisza köze déli részén. In: BenKő E. - BondÁr M. - Kolláth Á. (eds): Magyarország régészeti topográfiája. Múlt - jelen jövő. Budapest, 27-44.

BENKő E. 2011: Via regis - via gregis. Középkori utak a Pilisben. In: KővÁrI K. - MıKLós Zs. (eds): "Fél évszázad terepen". Tanulmánykötet Torma István tiszteletére 70. születésnapja alkalmából. Budapest, 115-119. 
Bintliff, J. 2002: Going to the Market in Antiquity. In: Olshausen, E. - Sonnabend, H. (eds): $Z u$ Wasser und zu Land. Verkehrswege in der antiken Welt. Stuttgarter Kolloquium zur historischen Geographie in Altertums 7, 1999. Stuttgart, 209-250.

Bíró, Sz. 2017: Die zivilen vici in Pannonien. Monographien des Römisch-Germanischen Zentralmuseums 131. Mainz.

Bolla I. 1983: A jogilag egységes jobbágyosztály kialakulása Magyarországon. Budapest.

Chisholm, M. 1979: Rural Settlement and Land Use. An Essay in Location. London.

Christaller, W. 1933: Die zentralen Orte in Süddeutschland. Jena.

CIL: Corpus Inscriptionum Latinarum.

Csontos, K. 1999: Pannonian Plated Fibulas. Antaeus 24, 157-168.

DAnielisová, A. 2015: Surplus Production and Basic Aspects of Subsistence Economy. In: Danielisová, A. - Fernández-Götz, M. (eds): Persistent Economic Ways of Living. Production, Distribution, and Consumption in Late Prehistory and Early History. Budapest, 103-118.

DÁLNOKI, O. 2009: Collected or Cultivated? Exotic and Indigenous Fruit Remains from Celtic to Roman Times in Pest County, Hungary. In: Morel, J.-P. - Mercuri, A. M. (eds): Plants and Culture: Seeds of the Cultural Heritage of Europe. Bari, 145-151.

Dinnyés I. - Kővári K. - Lovag Zs. - Tettamanti S. - Topál J. - Torma I. 1986: Pest megye régészeti topográfiája. A Budai és Szentendrei járás (XIII/1). Magyarország Régészeti Topográfiája 7. Budapest.

DövÉNyi Z. (ed.) 2010: Magyarország kistájainak katasztere. Budapest.

Ducke, B. - Kroefges, P. C. 2008: From Points to Areas: Constructing Territories from Archaeological Site Patterns Using an Enhanced Xtent Model. In: Posluschny, A. - Lambers, K. - Herzog, I. (eds): Layers of Perception. Proceedings of the 35th International Conference on Computer Applications and Quantitative Methods in Archaeology (CAA), Berlin, 2.-6. April, 2007. Kolloquien zur Vor- und Frühgeschichte 10. Bonn, 245-251.

ERdKamp, P. 1999: Agriculture, Underemployment, and the Cost of Rural Labour in the Roman World. Classical Quarterly 49/2, 556-572.

Ferenczi L. 2014: Molendium ad Aquas Calidas. A pilisi ciszterciek az állítólagos Fehéregyházán. Studia Comitatensia - Uj folyam 1, 145-267.

Ferenczi L. - LASZlovszky J. 2014: Középkori utak és határhasználat a pilisi apátság területén. Studia Comitatensia - Új folyam 1, 103-124.

FÜLÖp É. - HozÁK A. 2014: Magyarország mezőgazdálkodása a 18-19. században. Naszály.

Gyulai, F. 2010: Archaeobotany in Hungary. Seed, Fruit, Food and Beverage Remains in the Carpathian Basin from the Neolithic to the Late Middle Ages. Archaeolingua 21. Budapest.

HALSTEAD, P. 1995: Plough and power: the economic and social significance of cultivation with the ox-drawn ard in the Mediterranean. Bulletin on Sumerian Agriculture 8, 11-21.

HAvas Z. 2011: Új adalékok a római kori szőlőműveléshez Aquincum környékén. Budapest Régiségei 44, 183-197.

Havas Z. - Szeredi A. - Szilas G. - Terei Gy. - Líbor Cs. 2017: Megelőző feltárások a Bp. III., Csúcshegy-Harsánylejtő lelőhelyén 2016-ban (Preventive excavations in 2016 in Budapest III, Csúcshegy-Harsánylejtő archaeological site). Aquincumi Füzetek 23, 38-51.

Hobson, M. S. 2014: A Historiography of the Study of the Roman Economy: Economic Growth, Development, and Neoliberalism. In: Platts, H. - Pearce, J. - Barron, C. - Lundock, J. Yoo, J. (eds): TRAC 2013: Proceedings of the Twenty-Third Annual Theoretical Roman Archaeology Conference, King's College, London 2013. Oxford, 11-26.

Horváth I. - H. Kelemen M. - ToRma I. 1979: Komárom megye régészeti topográfiája. Esztergom és a Dorogi járás. Magyarország Régészeti Topográfiája 5. Budapest. 
Kocsis L. - Prohászka P. 2003: 214. Pilisszántó, Kálvária-dűlő. In: Kisfaludi J. (ed.): Régészeti kutatások Magyarországon 2001. Budapest, 204.

KovÁcs P. 1997: A „katonai territorium” és a veterani et cives Romani szervezet (Das „militärische Territorium" und die Organisation veterani et cives romani). Archaeologiai Értesitón 123-124, 49-62.

Kubinyi A. 1975: Budapest története a későbbi középkorban Buda elestéig (1541-ig). In: Gerevich L. KosÁry D. (eds): Budapest története a későbbi középkorban és a török hódoltság idején. Budapest, $7-240$.

Kubinyi A. 1996: A Magyar Királyság népessége a 15. század végén. Történelmi Szemle 38/2-3, 135-161.

Kubinyi, A. - Laszlovszky, J. 2018: Demographic Issues in Late Medieval Hungary: Population, Ethnic Groups, Economic Activity. In: Laszlovszky, J. - Nagy, B. - Szabó, P. - Vadas, A. (eds): The Economy of Medieval Hungary. Leiden-Boston, 48-63.

LaszLovszky, J. 1991: Social Stratification and Material Culture in the 10-14 ${ }^{\text {th }}$ Century Hungary. In: Kubinyi, A. - Laszlovszky, J. (eds): Alltag und materielle Kultur im mittelalterlichen Ungarn. Krems, 32-67.

Laszlovszky, J. 2018: Agriculture in Medieval Hungary. In: Laszlovszky, J. - Nagy, B. - Szabó, P. VADAS, A. (eds): The Economy of Medieval Hungary. Leiden-Boston, 81-112.

LAszlovszky, J. - NAgy, B. - Szabó, P. - VAdAs, A. 2018: Introduction: Hungarian Medieval Economic History: Sources, Research and Methodology. In: Laszlovszky, J. - Nagy, B. - Szabó, P. - VADAS, A. (eds): The Economy of Medieval Hungary. Leiden-Boston, 1-38.

Manen, J.-F. - Bouby, L. - Dálnoki, O. - Marinval, P. - Turgay, M. - Schlumbaum, A. 2003: Microsatellites from Archaeological Vitis vinifera Seeds Allow a Tentative Assignment of the Geographical Origin of Ancient Cultivars. Journal of Archaeological Science 30, 721-729.

Mesterházy K. 1991: A többosztatú falusi ház kialakulása. Századok 125, 68-78.

MrÁv, Zs. 2013: Graves of Auxiliary Soldiers and Veterans From the First Century AD in the Northern Part of Pannonia. In: SAnAder, M. - Rendić-MiočEvić, A. - Tončinić, D. - Radman-Livaja, I. (eds): Proceedings of the XVIIth Roman Military Equipment Conference: Weapons and Military Equipment in a Funerary Context (XVII Roman Military Equipment Conference, Zagreb, 24th 27th May, 2010). Zagreb, 87-16.

NAGY T. 1975: Budapest története az őskortól a honfoglalásig. In: Gerevich L. - KosÁry D. (eds.): Budapest története a későbbi középkorban és a török hódoltság idején. Budapest, 185-216.

Nemes Nagy J. 1998: A tér a társadalomtudományban. Budapest.

K. NÉMETH A. 2011: A középkori Tolna megye egyházi topográfiájának módszertani tapasztalatai. In: KőVÁri K. - Mikıós Zs. (eds): „Fél évszázad terepen”. Tanulmánykötet Torma István tiszteletére 70. születésnapja alkalmából. Budapest, 35-42.

OттомÁnyi K. 2012: Római vicus Budaörsön. In: OtтомÁnyi K. (ed.): Római vicus Budaörsön. Budapest, 9-408.

OттомÁnyi K. 2014: Újabb római vicusok Aquincum territoriumán. Dissertationes Archaeologicae 3/2, 97-142.

ŐRI P. 2002: Hatalom és demográfia. II. József népszámlálása Magyarországon I. In: ŐRI P. - FARAGó T. (eds): Történeti Demográfiai Évkönyv 2002. Budapest, 39-73.

ŐRI P. 2003: A demográfiai viselkedés mintái a 18. században. Lélekösszeírások Pest megyében, 17741783. Központi Statisztikai Hivatal Népességtudományi Kutatóintézetének Kutatási Jelentései 75. Budapest.

PÁlóczi Horváth A. 2006: Az elpusztult késő középkori falvak morfológiai variációi. Arrabona 44/1, 357-390.

Pető, Zs. E. 2014: Roman or Medieval? Historical roads in the Pilis forest. Hungarian Archaeology $2014 / 3,1-8$. 
RÁcz T. 2014: Az Árpád-kori települési formák változásai és terminológiája (Changes in the Árpád Age Settlement Formsand the Problems of Terminology). Studia Comitatensia - Uj folyam 1, 161-269.

RÁcz T. 2019: A Pesti síkság falvai a magyar honfoglalástól a 14. századig. Kerámiamüvesség, lakóépítmények, települési formák. Studia ad Archaeologiam Pazmaniensia 13. Budapest.

Renfrew, C. - Level, E. 1979: Exploring Dominance: Predicting Polities from Centers. In: Renfrew, C. Cooke, K. L. (eds): Transformations: Mathematical Approaches to Culture Change. New York, 145-166.

RIU: Die römische Inschriften Ungarns.

RupNik L. 2014: Római kori vasszerszámok Pannoniából. PhD dissertation. Eötvös Loránd University, Archaeology Doctoral Program. Budapest.

SimON, B. 2015: Roman settlement pattern and LCP modelling in ancient North-Eastern Pannonia (Hungary). Dissertationes Archaeologicae 3/3, 106-126.

Simon, B. 2017: Physical landscape and settlement pattern dynamics around Aquincum and Carnuntum. A socio-economic approach. Dissertationes Archaeologicae 3/5, 259-286.

Simon B. 2019: Aquincum és Brigetio mezőgazdasági hátországa és a katonaság ellátásának lokális rendszere. PhD Dissertation. Eötvös Loránd University, Archaeology Doctoral Program, Budapest.

StiBránYi M. 2017: A határon álló templomok. A középkori templomos helyek és a településhálózat vizsgálata Fejér megyében. In: BenKő E. - BondÁR M. - Kolláth Á. (eds): Magyarország régészeti topográfiája. Múlt - jelen - jövő. Budapest, 369-386.

SzŰ́cs J. 1981: Megosztott parasztság - egységesülő jobbágyság: a paraszti társadalom átalakulása a 13. században. 1-2. közlemény. Századok 115, 3-65, 263-314.

TAKÁcs M. 2015: A Medium Regni falusias településeinek anyagi kultúrája az Árpád- és Anjou-korban. In: BENKő E. - Orosz K. (eds): In medio regni Hungariae. Régészeti, müvészettörténeti és történeti kutatások „az ország közepén”. Budapest, 171-190.

TARI E. 2000: Pest megye középkori templomai. Studia Comitatensia 27, 1-372.

TitAq: Tituli Aquincenses.

von ThüNEn, J. H. 1826: Der isolierte Staat in Beziehung auf Landwirtschaft und Nationalökonomie. Rostock.

ToBLeR, W. 1993: Three presentations on geographical analysis and modelling. 1) Non-isotropic modelling 2) Speculations on the geometry of geography 3) Global spatial analysis. Santa Barbara.

Tомка B. 2005: Az összehasonlító módszer a történetírásban - eredmények és kihasználatlan lehetőségek. Aetas 20/1-2, 243-258.

Vionis, A. K. - Papantoniou, G. 2019: Central Place Theory Reloaded and Revised: Political Economy and Landscape Dynamics in the Longue Durée. Land 8;36, 1-21.

Wheatley, D. - Gillings, M. 2002: Spatial Technology and Archaeology. The archaeological applications of GIS. London-New York. 


\section{Catalogue of Roman villages (RCat)}

\section{Pilisszántó}

Literature: DinNYÉs et al. 1986, 17/1; 17/6.

National ID Nr. (KÖH): 11161; 11166

Coordinates Y, X (WGS 84): 47.662407; 18.884174

\section{Csobánka I}

Literature: DINNYÉs et al. 1986, 6/1.

National ID Nr. (KÖH): 10104

Coordinates Y, X (WGS 84): 47.668818; 18.945671

\section{Csobánka II}

Literature: DINNYÉs et al. 1986, 6/24; 6/27.

National ID Nr. (KÖH): 10127; 10130

Coordinates Y, X (WGS 84): 47.647202; 18.963356

\section{Pilisvörösvár}

Literature: DinnYÉs et al. 1986, 6/16; 21/3.

National ID Nr. (KOH): 10119; 11191.

Coordinates Y, X (WGS 84): 47.626950; 18.936822.

\section{Budakalász}

Literature: DinNYÉs et al. 1986, 3/32; 3/33.

National ID Nr. (KÖH): 10040; 10041

Coordinates Y, X (WGS 84): 47.630602; 19.011618

\section{Békásmegyer (vicus Vindonianus)}

Literature: Bíró 2017, Kat. 20.

National ID Nr. (KÖH): 60376

Coordinates Y, X (WGS 84): 47.606323; 19.054156

\section{Catalogue of Medieval villages (MeCat)}

\section{Beatae Mariae virginis / Cistercian abbey}

Literature: DinNyés et al. 1986, 19/1.

National ID Nr. (KÖH): 1174

Coordinates Y, X (WGS 84): 47.693277; 18.890971

Time of existence: $1184-1526$

\section{2. (Nagy)Szántó}

Literature: DINNYÉs et al. 1986, 17/9.

National ID Nr. (KÖH): 1169

Coordinates Y, X (WGS 84): 47.666250; 18.886087

Time of existence: $13^{\text {th }}$ c. -1541

\section{Kürt}

Literature: DiNNYÉs et al. 1986, 21/15.

National ID Nr. (KÖH): 11203

Coordinates Y, X (WGS 84): 47.638106; 18.893480

Time of existence: $13^{\text {th }}-$ end $14^{\text {th }} \mathrm{c}$. 


\section{Garancs}

Literature: DinNYÉs et al. 1986, 21/11.

National ID Nr. (KÖH): 11199.

Coordinates Y, X (WGS 84): 47.641766; 18.912817

Time of existence: $2^{\text {nd }}$ part of $13^{\text {th }}$ c. -1541

\section{5. (Kis)Szántó}

Literature: DinNYÉs et al. 1986, 21/22.

National ID Nr. (KÖH): 11210

Coordinates Y, X (WGS 84): 47.641766; 18.912817

Time of existence: $13^{\text {th }}$ c. -1541

\section{Wencia/Ivánfölde?}

Literature: DinNYÉs et al. 1986, 21/23.

National ID Nr. (KÖH): 11211

Coordinates Y, X (WGS 84): 47.618594; 18.874485

Time of existence: $13^{\text {th }} \mathrm{c}$. $-15^{\text {th }} \mathrm{c}$.

\section{Boron}

Literature: DinNyÉs et al. 1986, 6/10.

National ID Nr. (KÖH): 10113

Coordinates Y, X (WGS 84): 47.631786; 18.947555

Time of existence: $13^{\text {th }}$ c. -1541

\section{Kande}

Literature: DinNYÉs et al. 1986, 6/25.

National ID Nr. (KÖH): 10128

Coordinates Y, X (WGS 84): 47.612715; 18.955058

Time of existence: $13^{\text {th }}$ c. -1526

\section{Fedémes}

Literature: DinnYÉs et al. 1986, 6/26.

National ID Nr. (KÖH): 10129.

Coordinates Y, X (WGS 84): 47.621793; 18.963915.

Time of existence: $14^{\text {th }}$ c. -1541 .

\section{Unknown name (?) - Site name: Új-Klanác}

Literature: DinNYÉs et al. 1986, 6/4.

National ID Nr. (KÖH): 10107

Coordinates Y, X (WGS 84): 47.653010; 18.958425

Time of existence: $14^{\text {th }}-15^{\text {th }} c$.

\section{Borosjenö}

Literature: DinNYÉs et al. 1986, 15/6.

National ID Nr. (KÖH): 11133

Coordinates Y, X (WGS 84): 47.608012; 18.992043

Time of existence: $13^{\text {th }}$ c. -1541

\section{2. Üröm}

Literature: DinNYÉs et al. 1986, 37/10.

National ID Nr. (KÖH): 12030

Coordinates Y, X (WGS 84): 47.598466; 19.014129

Time of existence: $13^{\text {th }}$ c. -1541 


\section{Káloz}

Literature: DinNyÉs et al. 1986, 3/18.

National ID Nr. (KÖH): 10053

Coordinates Y, X (WGS 84): 47.617559; 19.047394

Time of existence: $12^{\text {th }} c . ?-1541$

\section{Kissing}

Literature: KubINyi 1975, 26; FerenCZI 2014, 153, 155.

National ID Nr. (KÖH): 69651

Coordinates Y, X (WGS 84): 47.607447; 19.070394

Time of existence: $14^{\text {th }}$ c. -1541

\section{Békásmegyer}

Literature: FERENCZI 2014, 153-154.

National ID Nr. (KÖH): -

Coordinates Y, X (WGS 84): 47.601522; 19.044409

Time of existence: $13^{\text {th }}$ c. -1541

16. Unknown name (Pazándok/Pócsernik?) - Site name: Csillaghegy-Téglagyár

Literature: Kubinyi 1975, 26-27; FerENCZi 2014, 153.

National ID Nr. (KÖH): 33354

Coordinates Y, X (WGS 84): 47.584595; 19.043401

Time of existence: $11^{\text {th }}-13^{\text {th }}$ c. $\left(15^{\text {th }}\right.$ c.? $)$

\section{Pazándok}

Literature: Kubinyi 1975, 26-27; FerEncZi 2014, 149-150, 1. kép.

National ID Nr. (KÖH): -

Coordinates Y, X (WGS 84): 47.571315; 19.058203

Time of existence: $13^{\text {th }}-15^{\text {th }} \mathrm{c}$.

\section{8. Óbudaörs}

Literature: KubINYi 1975, 28; FerEnCZI 2014, 1. kép.

National ID Nr. (KÖH): 36137

Coordinates Y, X (WGS 84): 47.575424; 19.012015

Time of existence: $13^{\text {th }}-15^{\text {th }} \mathrm{c}$.

\section{Beatae Mariae virginis / Fehéregyháza}

Literature: FERENCZI 2014, 1. kép.

National ID Nr. (KÖH): 36137

Coordinates Y, X (WGS 84): 47.547805; 19.027744

Time of existence: $10^{\text {th }}-15^{\text {th }} \mathrm{c}$.

\section{Gercse}

Literature: Kubinyi 1975, 27-28; FerencZi 2014, 1. kép.

National ID Nr. (KÖH): -

Coordinates Y, X (WGS 84): 47.564621; 18.979811

Time of existence: $13^{\text {th }}$ c. -1541

\section{Hidegkút}

Literature: KubINyi 1975, 27-28; FeRENCZI 2014, 1. kép.

National ID Nr. (KÖH): 54231

Coordinates Y, X (WGS 84): 47.565715; 18.959857

Time of existence: $13^{\text {th }}$ c. -1541 


\section{Sancti Spiritus / Pauline monastery}

Literature: HoRvÁth et al. 1979, 18/1.

National ID Nr. (KÖH): 2292

Coordinates Y, X (WGS 84): 47.734785; 18.843515

Time of existence: $13^{\text {th }}$ c. -1526

23. Unknown name (?) - Site name: Árpád-vár II.

Literature: HoRvátH et al. 1979, 6/8.

National ID Nr. (KÖH): 2008

Coordinates Y, X (WGS 84): 47.735383; 18.887398

Time of existence: $12^{\text {th }}-15^{\text {th }} c$.?

\section{Sanctae Crucis / Pauline monastery}

Literature: Horváth et al. 1979, 9/6.

National ID Nr. (KÖH): 2311

Coordinates Y, X (WGS 84): 47.700843; 18.834807

Time of existence: $13^{\text {th }}$ c. -1526

\section{Unknown name (?) - Site name: Margéta}

Literature: HoRvÁtH et al. 1979, 16/1.

National ID Nr. (KÖH): 2475

Coordinates Y, X (WGS 84): 47.682718; 18.833315

Time of existence: $10^{\text {th }}-13^{\text {th }} \mathrm{c}$.

\section{Kovácsi}

Literature: DinNYÉs et al. 1986, 23/12.

National ID Nr. (KÖH): 11252

Coordinates Y, X (WGS 84): 47.677116; 18.946641

Time of existence: $12^{\text {th }}$ c. -1526

\section{Aszófó}

Literature: DINNYÉs et al. 1986, 23/13.

National ID Nr. (KÖH): 11253

Coordinates Y, X (WGS 84): 47.660942; 18.989191

Time of existence: $12^{\text {th }}-14^{\text {th }} \mathrm{c}$.

\section{Pomáz}

Literature: DinnYÉs et al. 1986, 23/5.

National ID Nr. (KÖH): 11245

Coordinates Y, X (WGS 84): 47.652751; 19.025960

Time of existence: $12^{\text {th }}$ c. -1541

\section{Szencse}

Literature: DinNYÉs et al. 1986, 23/8.

National ID Nr. (KÖH): 11248

Coordinates Y, X (WGS 84): 47.636101; 19.038874

Time of existence: $10^{\text {th }}$ c. -1526

\section{Csaba}

Literature: DinNYÉs et al. 1986, 16/6.

National ID Nr. (KÖH): 11144

Coordinates Y, X (WGS 84): 47.632575; 18.836560

Time of existence: $13^{\text {th }}$ c. -1541 


\section{Solymár}

Literature: DinNYÉs et al. 1986, 25/4.

National ID Nr. (KÖH): 11415

Coordinates Y, X (WGS 84): 47.593538; 18.942681

Time of existence: $13^{\text {th }}$ c. -1541

\section{Kovácsi}

Literature: DinNYÉs et al. 1986, 12/2.

National ID Nr. (KÖH): 10805

Coordinates Y, X (WGS 84): 47.566641; 18.910072

Time of existence: $13^{\text {th }}$ c. -1526

\section{Catalogue of Modern villages (MoCat)}

Coordinates Y, X (WGS 84)

1. Pilisszentkereszt - 47.690306; 18.898173

2. Pilisszántó - 47.669880; 18.887164

3. Pilisvörösvár - 47.619213; 18.908327

4. Csobánka - 47.642828; 18.962622

5. Budakalász - 47.618922; 19.045970

6. Pilisborosjenő - 47.608012; 18.992043

7. Üröm - 47.598466; 19.014129

8. Békásmegyer - 47.601510; 19.044383

9. Pilisszentlélek - 47.726968; 18.843522

10. Pilismarót - 47.784144; 18.875338

11. Dömös $-47.763511 ; 18.911366$

12. Pilisszentlászló - 47.726863; 18.984347

13. Pomáz - $47.649620 ; 19.020227$

14. Óbuda - $47.538685 ; 19.044608$

15. Hidegkút - 47.566279; 18.960652

16. Solymár - 47.591262; 18.928125

17. Pilisszentiván - 47.609702; 18.897626

18. Piliscsaba $-47.631647 ; 18.825821$

19. Piliscsév - 47.678988; 18.819003

20. Kesztölc $-47.713443 ; 18.799020$ 